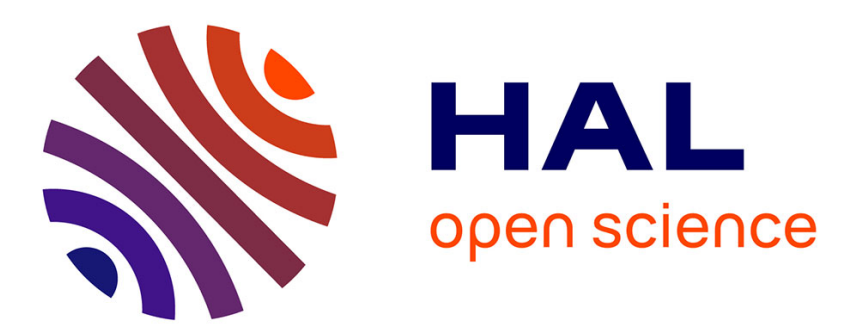

\title{
Assessment of strip tillage systems for maize production in semi-arid Ethiopia: effects on grain yield and water balance
}

\author{
M. Temesgen, J. Rockstrom, H. H. G. Savenije, W. B. Hoogmoed
}

\section{- To cite this version:}

M. Temesgen, J. Rockstrom, H. H. G. Savenije, W. B. Hoogmoed. Assessment of strip tillage systems for maize production in semi-arid Ethiopia: effects on grain yield and water balance. Hydrology and Earth System Sciences Discussions, 2007, 4 (4), pp.2229-2271. hal-00298860

\section{HAL Id: hal-00298860 https://hal.science/hal-00298860}

Submitted on 11 Jul 2007

HAL is a multi-disciplinary open access archive for the deposit and dissemination of scientific research documents, whether they are published or not. The documents may come from teaching and research institutions in France or abroad, or from public or private research centers.
L'archive ouverte pluridisciplinaire HAL, est destinée au dépôt et à la diffusion de documents scientifiques de niveau recherche, publiés ou non, émanant des établissements d'enseignement et de recherche français ou étrangers, des laboratoires publics ou privés. 
Hydrol. Earth Syst. Sci. Discuss., 4, 2229-2271, 2007 www.hydrol-earth-syst-sci-discuss.net/4/2229/2007/

(C) Author(s) 2007. This work is licensed under a Creative Commons License.
Hydrology and

Earth System

Sciences

Discussions

Papers published in Hydrology and Earth System Sciences Discussions are under open-access review for the journal Hydrology and Earth System Sciences

\section{Assessment of strip tillage systems for maize production in semi-arid Ethiopia: effects on grain yield and water balance}

M. Temesgen ${ }^{1,3}$, J. Rockstrom ${ }^{2}$, H. H. G. Savenije ${ }^{1,3}$, and W. B. Hoogmoed ${ }^{4}$

${ }^{1}$ UNESCO-IHE, Delft, The Netherlands

${ }^{2}$ Stockholm Environment Institute, Box 2142, 10314 Stockholm, Sweden

${ }^{3}$ Delft University of Technology, P. O. Box 5048, 2601 DA Delft, The Netherlands

${ }^{4}$ Farm Technology Group, Wageningen University, P.O. Box 17, 6700 AA Wageningen, The Netherlands

Received: 8 May 2007 - Accepted: 14 May 2007 - Published: 11 July 2007

Correspondence to: M. Temesgen (melesse_tem @yahoo.com)

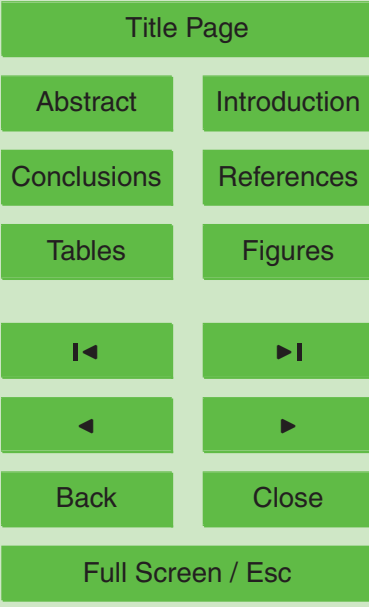

Printer-friendly Version

Interactive Discussion 


\section{Abstract}

The traditional tillage implement, the Maresha plow, and the tillage systems that require repeated and cross plowing have caused poor rainfall partitioning, land degradation and hence low water productivity in Ethiopia. Conservation tillage could al-

5 leviate these problems. However, no-till can not be feasible for smallholder farmers in semi-arid regions of Ethiopia because of difficulties in maintaining soil cover due to low rainfall and communal grazing and because of high costs of herbicides. Strip tillage systems may offer a solution. This study was initiated to test strip tillage systems using implements that were modified forms of the Maresha plow, and to evaluate pacts of the new tillage systems on water balance and grain yields of maize (Zea mays $X X$ ). Experiments were conducted in two dry semi arid areas called Melkawoba and Wulinchity, in the central Rift Valley of Ethiopia during 2003-2005. Strip tillage systems that involved cultivating planting lines at a spacing of $0.75 \mathrm{~m}$ using the Maresha plow followed by subsoiling along the same lines (STS) and without subsoiling (ST) were compared with the traditional tillage system of 3 to 4 times plowing with the Maresha plow (CONV). Soil moisture was monitored to a depth of $1.8 \mathrm{~m}$ using Time Domain Reflectometer while surface runoff was measured using rectangular trough installed at the bottom of each plot. STS resulted in the least surface runoff $\left(Q s=17 \mathrm{~mm}^{- \text {season }^{-1}}\right)$, the highest transpiration $\left(T=196 \mathrm{~mm}\right.$-season $\left.{ }^{-1}\right)$, the highest 20 grain yields $\left(Y=2130 \mathrm{~kg}^{-} \mathrm{ha}^{-1}\right)$ and the highest water productivity using total evapora-

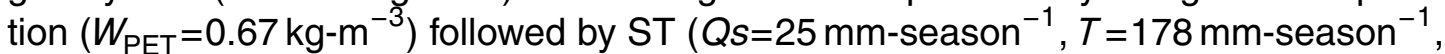
$\left.Y=1840 \mathrm{~kg}^{-\mathrm{ha}^{-1}}, W_{\mathrm{PET}}=0.60 \mathrm{~kg}-\mathrm{m}^{-3}\right)$ and CONV $\left(Q s=40 \mathrm{~mm}\right.$-season ${ }^{-1}, T=158 \mathrm{~mm}$ season $\left.^{-1}, Y=1720 \mathrm{~kg}-\mathrm{ha}^{-1}, W_{\mathrm{PET}}=0.58 \mathrm{~kg}-\mathrm{m}^{-3}\right)$. However, when the time between the last tillage operation and planting of maize was more than 26 days, the reverse occurred. There was no statistically significant change in soil physical and chemical properties after three years of experimenting with different tillage systems.
HESSD

4, 2229-2271, 2007

Water productivity of conservation tillage systems

M. Temesgen et al.

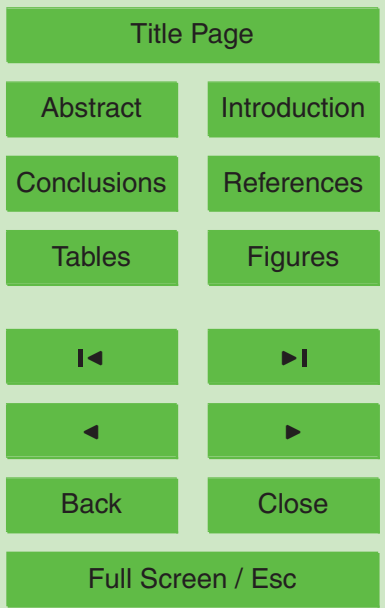

Printer-friendly Version

Interactive Discussion 


\section{Introduction}

The traditional tillage implement in Ethiopia, is the Maresha (Fig. 1). Soil management using this simple ard plough requires repeated passes and cross plowing causing land degradation (Bezuayehu et al., 2002), delayed planting and high drudgery to both draft 5 animals and human beings (Pathak, 1987). Poor soil structure results in poor rainwater retention and infiltration (Rockström and Valentin, 1997; Hoogmoed, 1999) while delayed planting shortens the length of the growing period available for the crop (Rowland, 1993).

The poor timeliness of operations is a serious problem for smallholder farmers in 10 Ethiopia who cultivate $95 \%$ of the land under agriculture with more than $60 \%$ of them owning only one or no ox at all (Pathak, 1987). Small seeded cereals like tef (Eragrostis tef (Zucc) Trotter) require 5 to 9 passes with the Maresha plow in high rainfall areas (Taddele, 1994; Teklu and Gezahegn, 2003) whereas maize in the low rainfall areas require 4 passes. Moreover, due to the geometry of the traditional tillage implement, 15 farmers are forced to carry out cross ploughing which orients tillage direction along the slope in one of two consecutive tillage operations thereby encouraging surface runoff (Temesgen et al., 2007).

Introduction of conservation tillage practices using appropriate equipment can help farmers improve soil quality for sustainable agriculture (Chen et al., 1998; Steiner, 1998; Rockström and Jonsson, 1999; Biamah and Rockström, 2000; Freitas, 2000; Hoogmoed et al., 2004). However, reduced or no tillage without soil cover results in reduced infiltration and lower grain yields (Georgis and Sinebo, 1993; Akinyemi et al., 2003; Guzha, 2004). Such problems are inevitable in areas where lack of offseason rainfall and dry season feed shortage make it difficult to cover the soil either with crop residues or cover crops. This is typically the case in semi-arid Ethiopia, and this situation calls for an alternative approach. A strip tillage system may offer a solution.

Strip tillage systems where planting lines are cultivated while the inter-row space is

\section{HESSD}

4, 2229-2271, 2007

\section{Water productivity of conservation tillage systems}

M. Temesgen et al.

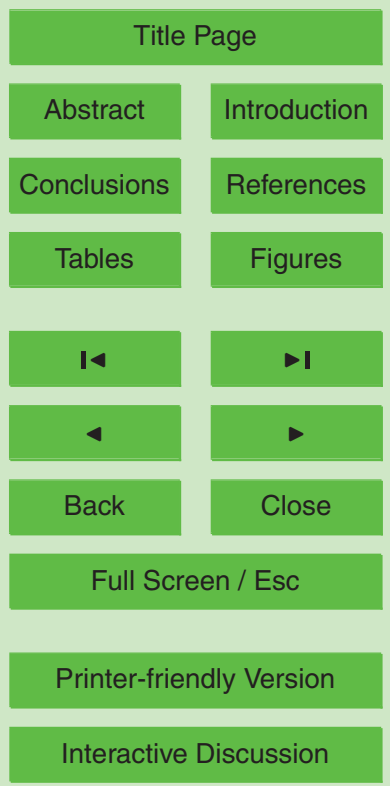

EGU 
left undisturbed have been found to have the benefits of both no tillage and conventional tillage (Licht and Al-Kaisi, 2005). Moreover, strip tillage systems allow the farmer to plow only in one direction, along the contour, so as to prevent surface runoff. Tillage time is reduced thus enabling farmers to complete land preparation in time and to 5 reduce the oxen time required, which can be particularly beneficial to resource poor farmers who own only one or no oxen at all.

This paper reports on experiments evaluating a strip tillage system for maize production in two semi arid areas in Ethiopia. Traditional and improved tillage systems were evaluated for their impact on grain yield, soil water balance, and soil physical and 10 chemical properties.

\section{Materials and methods}

\subsection{Experimental site}

The study has been undertaken at Melkawoba and Wulinchity areas (Figure 2), which are typical dry semi-arid regions located in the central rift valley of Ethiopia. The two areas were chosen for their representations of the climates in the dry semi-arid regions (Engida, 2000). Within the dry semi arid category, Wulinchity is relatively wetter and with heavier soils than Melkawoba.

Melkawoba is located $08^{\circ} 23^{\prime}$ North Latitude and $039^{\circ} 22^{\prime}$ East Longitude with an altitude of $1450 \mathrm{~m}$ above sea level. The mean rainfall is $600 \mathrm{~mm}-\mathrm{yr}^{-1}$ (Fig. 3) with a potential evaporation of $2300 \mathrm{~mm}^{-\mathrm{yr}^{-1}}$. The rain is distributed over a period of 7 months (March-September) with two distinctive seasons (short rains in March and April are followed by the main rain season of June-September). The soil types are mainly sandy loam (Calcaric Cambisols) and very susceptible to compaction similar to the so called sealing, crusting and hard-setting $(\mathrm{SCH})$ soils that are common in sub-Saharan

25 Africa (Hoogmoed, 1999). Complete crop failure due to dry spells is not uncommon in the area. The major crops are tef (Eragrostis tef (Zucc.)) and maize (Zea mays XX).
HESSD

4, 2229-2271, 2007

\section{Water productivity of conservation tillage systems}

M. Temesgen et al.

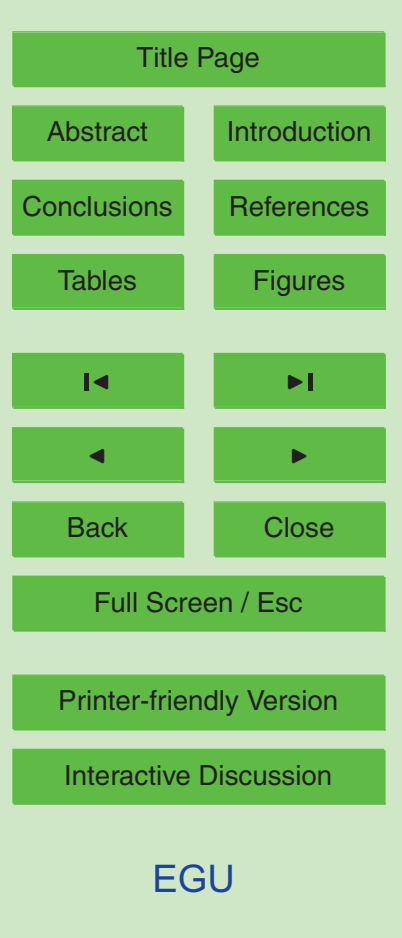


Wulinchity is located $08^{\circ} 40^{\prime}$ North Latitude and $039^{\circ} 26^{\prime}$ East Longitude with an altitude of $1447 \mathrm{~m}$ above sea level. The soils are predominantly clay loam (Eutric Cambisols). The mean rainfall is $700 \mathrm{~mm}^{-\mathrm{yr}^{-1}}$ (Fig. 3) while the mean potential evaporation is $2200 \mathrm{~mm}-\mathrm{yr}^{-1}$. The rainfall distribution is similar to that of Melkawoba but usually sufficient rainfall is received during March and April to enable farmers to start tillage earlier. The types of crops grown at Wulinchity are similar to those of Melkawoba.

\subsection{Treatments}

Three parallel treatments have been tested:

1. Conventional tillage (CONV) in which the land was plowed three to four times depending on the rainfall situation and according to farmers' practice.

2. Strip tillage system (ST) in which the planting lines were cultivated using the Maresha plow at $0.75 \mathrm{~m}$ spacing.

3. Strip tillage system with subsoiling (STS) in which the planting lines were cultivated using the Maresha plough followed by subsoiling with a Maresha modified Subsoiler (Fig. 4) over the same furrows

In 2003 and 2004, the design was a completely randomized block with 8 replications at each site whereas in 2005, ten replications were made. Each plot was $10 \mathrm{~m}$ by $10 \mathrm{~m}$. A short cycle maize variety, Katumani, was planted in rows of $0.75 \mathrm{~m}$ spacing at a rate of $30 \mathrm{~kg}^{-\mathrm{ha}^{-1}}$. In 2003 and 2004, the plots were split into subplots with and without 20 fertilizer. Fertilizer was applied at a rate of $100 \mathrm{~kg}^{-h a^{-1}}$ Di-Amonium Phosphate $(23 \mathrm{~kg}$ $\mathrm{N}$ and $46 \mathrm{~kg} \mathrm{P}_{2} \mathrm{O}_{5}$ ) at planting and $50 \mathrm{~kg}-\mathrm{ha}^{-1}$ Urea 35 days after planting.

In the year 2005, all plots were fertilized. Moreover, due to early onset of rainfall in 2005 six blocks were planted with a medium maturing local maize variety, called Limat, on 17 May 2005. Four other blocks were planted with an early maturing maize variety 25 called Katumani. Water balance studies were carried out in two of the four late planted
HESSD

4, 2229-2271, 2007

Water productivity of conservation tillage systems

M. Temesgen et al.

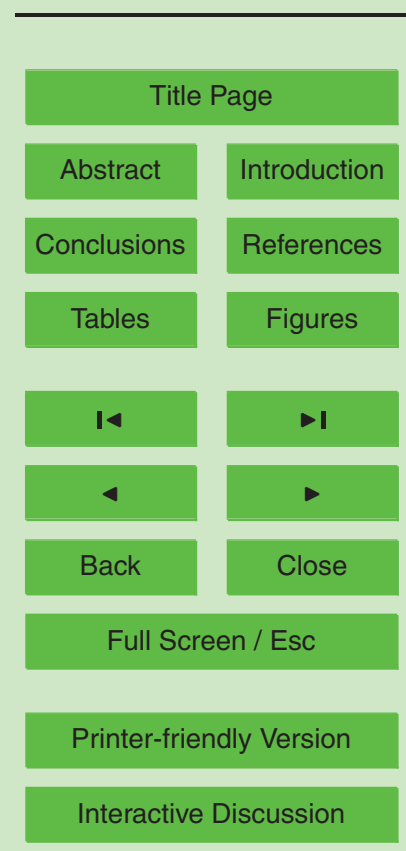

EGU 
blocks. Moreover, the furrows made along planting lines in the conservation tillage treatments (STS and ST) were closed with a second pass adjacent to the previous as opposed to leaving them open. A separate experiment was also carried out comparing open and closed furrows both in STS and ST treatments to observe the effect of closing 5 the furrows.

\subsection{Water balance}

Daily rainfall was measured at 09:00 o'clock using two rain gauges installed near the experimental plots. Pan evaporation, $E_{p}$, was measured daily at 09:00, 12:00 and at 15:00 h using a Class A-pan installed near the experimental plots. Surface runoff was collected using a $0.5 \mathrm{~m} \times 0.25 \mathrm{~m} \times 10 \mathrm{~m}$ trough installed at the bottom of each of the $10 \mathrm{~m} \times 10 \mathrm{~m}$ plot (Fig. 5 ). The volume of water thus collected was manually scooped and measured using a 20-I container and a graduated glass jar. Soil moisture was monitored using a Time-Domain Reflectometer (TDR) moisture measuring equipment from Eijkelkamp $®$ and access tubes buried to depths of $1.8 \mathrm{~m}$. Two tubes were installed on each plot in $0.04 \mathrm{~m}$ diameter holes drilled using hand augers. The holes were located $4.5 \mathrm{~m}$ from the North-West and South-East corners of each plot along the diagonal line that connects the two corners. With two replications, there were four tubes for each treatment. The mean values of data collected from the four tubes were used for the analysis.

$20 \quad$ The leaf area index $\left(I_{L A}\right)$ expressed as $\mathrm{m}^{2}-\mathrm{m}^{-2}$, was determined by measuring the maximum width and length of leaves on randomly selected 5 plants in each plot with a pocket meter at 30 and 60 days after planting. The leaf area $(A)$ was calculated with the equation of Stewart and Dwyer (1999). Thus,

$A=\alpha W_{M} L$

25 where $\alpha$ is a coefficient with a value of 0.75 for the short stature maize variety used in our experiment, $W_{M}$ is the maximum width of the leaf and $L$ is the length of the leaf.

HESSD

4, 2229-2271, 2007

Water productivity of conservation tillage systems

M. Temesgen et al.

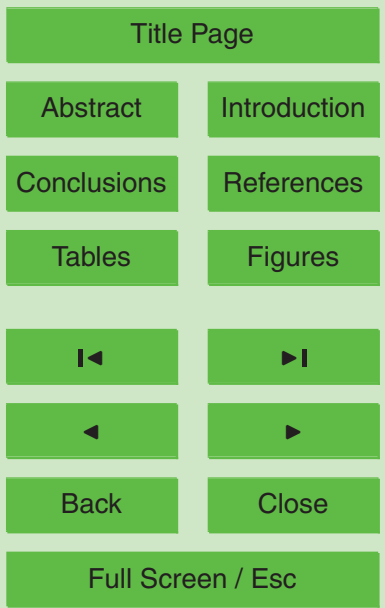

Printer-friendly Version

Interactive Discussion 
$I_{L A}$ was calculated by adding the areas of all the leaves in each plant and dividing the sum by the area of land covered by each plant (Antunes et al., 2001), which also means multiplying the total area of a single leaf by the population, $P_{0}$. Thus,

$I_{L A}=P_{0} \sum_{i=1}^{n} A_{i}$

5 where $P_{0}$ is plant population per $\mathrm{m}^{2}$ and $n$ is the number of leaves in each plant.

\subsection{Modelling the water balance}

A simple conceptual model (Fig. 6) was used to estimate the various components of the total evaporation (soil evaporation, transpiration and interception) and loss of water below the root depth. The model assumes that a certain proportion of the precipitation 10 is intercepted by the canopy and soil surface, which is fed back to the atmosphere within the same day before it is partitioned between infiltration and surface runoff (Savenije, 2004).

A threshold $D$ of $4 \mathrm{~mm}^{-1} \mathrm{~d}^{-1}$ was assumed for interception, resulting in the simple threshold function:

${ }_{15} \quad I=\min (P, D)$

where / $\left(\mathrm{mm}-\mathrm{d}^{-1}\right)$ is the evaporation from interception. The change in soil water storage was calculated using the water balance equation:

$\frac{\mathrm{d} S}{\mathrm{~d} t}=P-I-Q_{S}-T-E_{S}-R$

where $\mathrm{d} S / \mathrm{d} t\left(\mathrm{~mm}-\mathrm{d}^{-1}\right)$ is the change in storage of water over the root depth (top $1 \mathrm{~m}$ ), ${ }_{20} P\left(\mathrm{~mm}^{-\mathrm{d}^{-1}}\right)$ is the precipitation, $/$ is interception, $Q_{S}\left(\mathrm{~mm}^{-\mathrm{d}^{-1}}\right)$ is surface runoff, $T(\mathrm{~mm}$ $\left.\mathrm{d}^{-1}\right)$ is transpiration by the plant, $E_{s}\left(\mathrm{~mm}^{\left.-\mathrm{d}^{-1}\right)}\right.$ is evaporation from the soil and $R(\mathrm{~mm}-$ $\mathrm{d}^{-1}$ ) is deep absorption below $1 \mathrm{~m}$.
HESSD

4, 2229-2271, 2007

Water productivity of conservation tillage systems

M. Temesgen et al.

Title Page

Abstract

Introduction

Conclusions

References

Tables

Figures

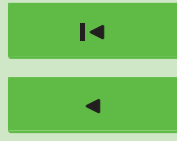

$>$ I

Back

Close

Full Screen / Esc

Printer-friendly Version

Interactive Discussion 
When there is no limitation in soil moisture, plant transpiration is assumed to be related to the leaf area index, $I_{L A},\left(\mathrm{~m}^{2}-\mathrm{m}^{-2}\right)$ the crop parameter, $K_{c}$, that also takes care of the pan coefficient, the pan evaporation, $E_{P}\left(\mathrm{~mm}-\mathrm{d}^{-1}\right)$, and $/$. Accordingly,

$T_{0}=I_{L A} \max \left(K_{C} E_{P}-I, 0\right)$

5 where $T_{0}$ is the non-moisture-constrained transpiration. A value of 0.65 was assigned for $K_{C}$ (Table 1). However, when the soil water storage in the root zone, $S$, is below a certain value related to field capacity, $S_{F C}$, the transpiration is reduced to a level determined by the curve that relates the ratio of actual transpiration to potential transpiration, $T / T_{0}$, with soil water storage, $S$ (Fig. 7).

10 The slope of the curve, $K$, is given by:

$K=\frac{1}{(1-p)\left(S_{F C}-S_{W}\right)}$

where $(1-p)$ is the fraction of soil water available to the crop $\left(S_{F C}-S_{W}\right)\left(\mathrm{mm}-\mathrm{m}^{-1}\right)$ in which transpiration is limited by moisture stress (Savenije, 1997). The ratio, $T / T_{O}$, is, therefore, given by:

${ }_{15} T / T_{0}=K\left(S-S_{W}\right)$

Combining Eqs. (5) to (7) yields,

$T=I_{L A} \max \left(K_{C} E_{p}-I, 0\right) \max \left[\min \left(\frac{S-S_{W}}{(1-p)\left(S_{F C}-S_{W}\right)}, 1\right), 0\right]$

Soil evaporation, $E_{S}$, is calculated using a similar concept as that of transpiration (Fig. 8). The canopy cover will affect $E_{S}$ when $I_{L A}$ is greater than 0.3 and hence the

\section{HESSD}

4, 2229-2271, 2007

Water productivity of conservation tillage systems

M. Temesgen et al.

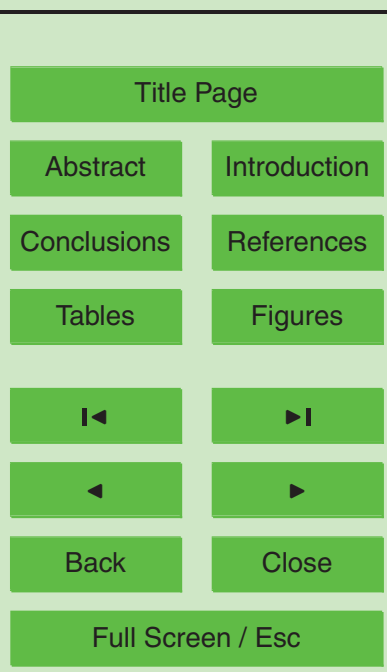

Printer-friendly Version

Interactive Discussion 
Water in excess of the field capacity of the soil is assumed to be drained from the root zone. Moreover, water absorption below the root depth occurs as a result of moisture gradient even before the soil moisture reaches field capacity. Thus, loss of water below the root zone,

$R=S-S_{F C}, S>S_{F C}$

$\left.{ }^{5} R=K_{R} \max \left(S-(1-r) S_{F C}\right), 0\right), S \leq S_{F C}$

where $K_{R}$ is a parameter that takes account of the share of deep absorption from storage in the root zone.

The change in storage is calculated using Eq. (4). Calibration of the model is carried out using the results of the first treatment (CONV) while the second and the third treatments (STS and ST) were used to validate the model. The validated model was then used to estimate water balance components for the years 2004 and 2003.

\subsection{Water productivity}

Water productivity has been calculated as the ratio of grain yield to total rainfall, total evaporation and transpiration using the formulae:

$W_{P}=\frac{Y}{P}$

$W_{\mathrm{PET}}=\frac{Y}{\left(P-Q_{S}-R\right)}$

$W_{P T}=\frac{Y}{T}$

Where $W_{P}, W_{\mathrm{PET}}$ and $W_{P T}$ are water productivity in $\mathrm{kg}-\mathrm{m}^{-3}$ for total rainfall, total evaporation (soil evaporation, plant transpiration and interception) and plant transpiration,
HESSD

4, 2229-2271, 2007

Water productivity of conservation tillage systems

M. Temesgen et al.

Title Page

Abstract

Introduction

Conclusions

References

Tables

Figures

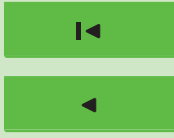

$\rightarrow$

Back

Close

Printer-friendly Version

Interactive Discussion 


\subsection{Grain yield}

The crop was harvested leaving out one meter from each end and one row from each side of the plot. The total weight of above ground biomass was measured using a stationary balance of $20 \mathrm{~kg}$ capacity in the field. The cobs were carefully removed and

5 shelled by hand and weighed. Moisture content of the grain was determined by drying in an oven at $70^{\circ} \mathrm{C}$ for $24 \mathrm{~h}$ and grain yields were adjusted to a moisture content of $15.5 \%$. Statistical analysis on the data was carried out using the SAS software (SAS Institute Inc., 1999).

\subsection{Soil physical and chemical properties}

10 Soil organic carbon (SOC), bulk density (BD), and total nitrogen (TN) and pH were measured before the experiment was started in May 2003 (Table 2). Samples were taken from the $0-0.15 \mathrm{~m}$ layer at 9 randomly selected points in the experimental field. Another 9 samples were collected up to a depth of $1.2 \mathrm{~m}$ from the same fields for textural analysis. At the end of the experiment, in November 2005, the same properties were measured from three randomly selected spots in each plot, after the crop was harvested.

The analyses were conducted according to the procedures outlined in Van Reeuwijk (1993). The particle size distribution (sand, $0.05-2.00 \mathrm{~mm}$; silt, $0.002-0.05 \mathrm{~mm}$; and clay, $<0.002 \mathrm{~mm}$ ) was determined by the hydrometer method after organic matter removal. SOC was determined by the Walkley-Black method while TN was determined by the wet-oxidation procedure of the Kjeldahl method. The soils were classified according to the World Reference Base for Soil Resources (ISSS-ISRIC-FAO, 1998).

HESSD

4, 2229-2271, 2007

Water productivity of conservation tillage systems

M. Temesgen et al.

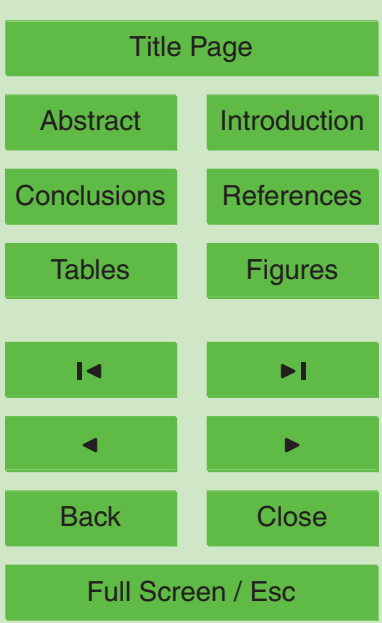

Printer-friendly Version

Interactive Discussion 


\section{Results and discussion}

\subsection{Water balance}

HESSD

Regression analysis of data on rainfall and surface runoff yielded the relationships shown in Eqs. (12)-(14). The figures in the bracket were used as thresholds to calcu-

5 late the net rainfall.

$Q_{S(\mathrm{CONV})}=0.20(P-6.5)$

$R^{2}=0.7$

Where $Q_{S}$ is surface runoff in $\mathrm{mm}-\mathrm{d}^{-1}$ and $P$ is rainfall in $\mathrm{mm}-\mathrm{d}^{-1}$.

$Q_{S(\mathrm{STS})}=0.09(P-5)$

$R^{2}=0.5$

$Q_{S(\mathrm{ST})}=0.13(P-6.5)$

$R^{2}=0.6$

10 Figure 9 shows the relationship between net rainfall and surface runoff.

Surface runoff in CONV was the highest probably because of plowing up and down the slope. On the other hand, the unplowed parts of the STS/ST treatments may have retarded the movement of water. Moreover, the subsoiled plots could have more infiltration resulting in the lowest surface runoff. With reductions in surface runoff and hence possibly reduction in soil erosion, it is expected that the STS/ST treatments will have added benefits in the long term.

\subsubsection{Model outputs}

Soil evaporation, transpiration and drainage: Table 3 shows the model outputs on water balance components. STS has the highest transpiration to precipitation ratio

followed by ST (See Fig. 10 and Table 3). This is because of reduced surface runoff

Water productivity of conservation tillage systems

M. Temesgen et al.

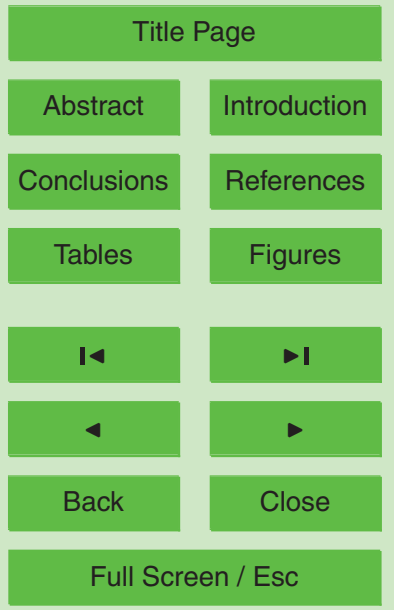

Printer-friendly Version

Interactive Discussion 
which makes more water available in the root zone. The ratio of the non-productive evaporation $\left(I+E_{S}\right)$ to the precipitation is also the lowest in STS followed by ST. The calibration and validation of the conceptual model are shown in Fig. 11a and Figs. 11b, $c$, respectively. The simple conceptual model simulated the soil moisture very well.

HESSD

4, 2229-2271, 2007

Water productivity of conservation tillage systems

Monthly rainfall distribution over the experimental seasons is shown in Figure 12. Generally, 2004 was a relatively dry season not because the annual rainfall is so low but because the distribution was not good. That means, during the main season, the rainfall was the lowest in 2004 whereas the distribution and the amount of rainfall in 2005 distribution of rainfall. The results are shown in Table 4.

It is interesting to note that in the year 2005, the results were in favor of conventional tillage for medium maturing maize variety while the conservation tillage treatments gave higher yields for the early maturing maize variety. For the medium maturing maize 15 variety, participating farmers commented that the soil in STS/ST treatments lost more moisture because of higher soil evaporation than in CONV. This was because the time between the date of the last tillage in STS/ST and planting (DTP) was longer (48 days), in the case of the medium maturing variety, while DTP was 6 days in the case of the early maturing variety (Fig. 13). The effect of higher DTP could be higher loss of soil moisture due to transpiration by weeds as the latter were not controlled. Similar trends were also observed in the results of the previous years. In 2003, DTP was 26 and 23 days at Melkawoba and Wulinchity, respectively, while in 2004 there was a 59 and 56 days gap at Melkawoba and Wulinchity, respectively, which could have lowered grain yield from ST/STS relative to CONV in 2004 as compared to that of 2003.

$25 \quad$ When comparing the two situations with extended DTP of 48 and 59 days, we find that the effect of the gap was higher when DTP was 48 days than when it was 59 days (Fig. 13). This could be because of differences in the amount of rainfall received during the two gaps. The rainfall received during the gaps was $105 \mathrm{~mm}$ in 2005 and

\section{Temesgen et al.}

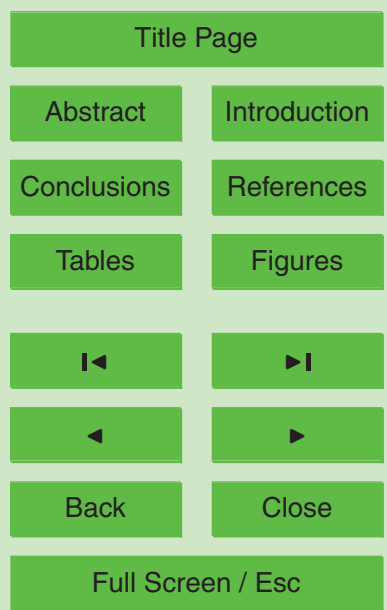

Printer-friendly Version

Interactive Discussion 
$65 \mathrm{~mm}$ in 2004. Higher cumulative rainfall in the 48 days gap could have caused more compaction (Ndiaye et al., 2005). The grain yields are also higher in 2005 than in 2004.

The results indicate that it may be necessary to cultivate the planting lines in STS/ST treatments at a shallow depth using the winged cultivator (Temesgen et al., 2007) in 5 situations where longer periods between tillage commencement and planting are encountered. The winged cultivator could help in controlling weeds thereby reducing weed transpiration while at the same time breaking crust for increased infiltration and sealing vertical channels for reduced evaporation, without exposing the lower moist soil layers. Moreover, the option of late subsoiling such as one week before planting or 10 after planting should be tested.

Closing planting furrows in STS/ST treatments showed significantly higher grain yield compared to leaving them open (Table 5). The reason could be higher loss of moisture over the planting zone in the open furrows. Rough surfaces could reduce surface runoff during heavy storms by acting as barriers to movement of water but they can cause higher soil evaporation during dry spells.

During 2003 and 2004, fertilizer was applied in split plots. The effect of fertilizer was significant in most cases (Table 6). There was no interaction between tillage system and fertilization.

\subsection{Water productivity}

20 Table 7 reveals that in the year 2005, when we had better performance of the conservation tillage treatments particularly, STS, water productivity for total rainfall $\left(W_{P P}\right)$ showed the highest value for STS thus reflecting on the performance of the tillage system. As explained in the Materials and Methods section, this is because STS had the least surface runoff, which means more of the rain water was used for crop production.

25 It is evident from Table 7 that water productivity for transpiration $\left(W_{P T}\right)$ did not show appreciable differences among the treatments. Had we compared different crops or crop varieties we could have found significant differences in $W_{P T}$ because for the same amount of transpired water, different crops or different crop varieties would give differ-
HESSD

4, 2229-2271, 2007

\section{Water productivity of conservation tillage systems}

M. Temesgen et al.

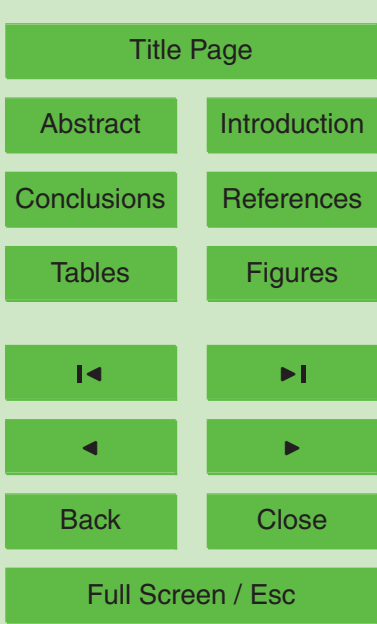

Printer-friendly Version

Interactive Discussion 
ent grain yields. However, water productivity for total amount of evaporation ( $\left.W_{\mathrm{PET}}\right)$ appeared to be a better way of assessing water productivity than transpiration alone. This could be because of vapor shift (Rockström, 2003), which reduce soil evaporation as biomass production increases in water conserving treatments, which reduced 5 surface runoff. The effect of vapor shift in increasing $W_{\mathrm{PET}}$ resulted in a more efficient use of the depleted (evaporated) water in STS than in CONV. This will have a positive contribution to the water productivity on both watershed and basin scales.

\subsection{Soil properties}

Tillage treatments did not significantly alter soil physical and chemical properties after a 10 period of three years (Table 8). According to some literature, the SOC and TN contents of soils take longer ( $>5$ years) to respond to reduced tillage (West and Post, 2002; Heenan et al., 2004) while others reported significant changes in shorter periods of two to three years (Su et al., 2004; Ozpinar and Cay, 2006). Although, statistically non significant, there is a tendency for improvement in SOC and TN. The increase in SOC and TN in the less plowed soils could be due to the decreased mineralization rate of soil organic matter (Ozpinar and Cay, 2006). High temperatures in the study area (average maximum $31^{\circ} \mathrm{C}$ and minimum $15^{\circ} \mathrm{C}$ ) could cause high oxidation of organic carbon (Clark and Gilmour, 1983).

\section{Conclusions}

20 The strip tillage system that involved subsoiling (STS) resulted in the least surface runoff, highest plant transpiration and highest grain yield followed by the strip tillage system without subsoiling (ST) when the days between the last tillage operations in STS/ST and planting (DTP) was 6 days. The reverse occurred when DTP was longer than 26 days.

A simple conceptual model simulated soil moisture reasonably well. Closing furrows

\section{HESSD}

4, 2229-2271, 2007

Water productivity of conservation tillage systems

M. Temesgen et al.

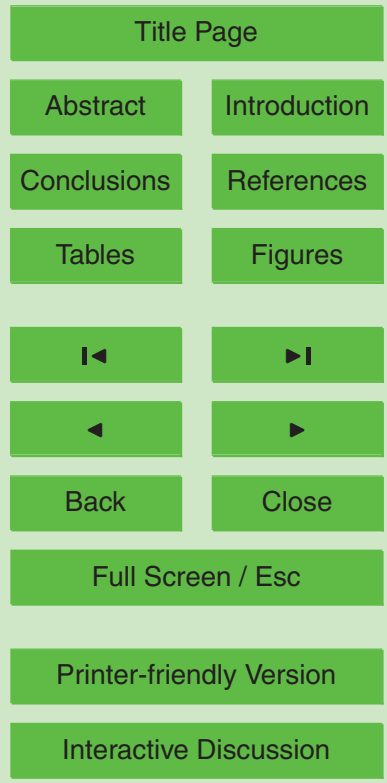

EGU 
in STS/ST treatments gave significantly higher grain yield apparently because of reduced soil evaporation. Fertilization had a significant effect on grain yield of maize. Water productivity for total evaporation and rainfall was the highest in STS showing efficient use of rainwater by the tested conservation tillage practice.

$5 \quad$ Tillage systems had no significant effect on soil physical and chemical properties after the three years period of the experiment. It is recommended that additional studies be carried out in order to verify the effects of time of subsoiling on rainfall partitioning and yields of maize.

Acknowledgements. The research was financed by the Regional Land Management Unit 10 (RELMA) in ICRAF, the Dutch Foundation for Tropical Research (WOTRO) and the International Foundation for Science (IFS).

\section{References}

Akinyemi, J. O., Akinpelu, O. E., and Olaleye, A. O.: Performance of cowpea under three tillage systems on an Oxic Paleustalf in southwestern Nigeria, Soil Till. Res., 72, 75-83, 2003.

15 Antunes, M. A. H., Walter-Shea, E. A., and Mesarch, A. M.: Test of an extended mathematical approach to calculate maize leaf area index and leaf angle distribution, Agric. Forest Meteorol., 108, 45-53, 2001.

Bauer, A. and Black, A. L.: Quantification of the effect of soil organic matter content on soil productivity, Soil Sci. Soc. Am. J., 58, 185-193, 1994.

20 Bezuayehu, T., Gezahegn, A., Yigezu, A., Jabbar, M. A., and Paulos, D.: Nature and causes of land degradation in the Oromiya Region: A review. Socio-economics and Policy Research Working Paper 36. ILRI (International Livestock Research Institute), Nairobi, Kenya. 34p, 2002.

Biamah, E. K. and Rockström, J.: Development of sustainable conservation tillage systems, in: Conservation Tillage for Dryland Farming. Technological Options and Experiences in Eastern and Southern Africa. Nairobi: Regional Land Management Unit, edited by: Biamah, E. K., Rockström, J., and Okwach, G. E., Swedish International Development Agency (Sida), 2000. RELMA Workshop Report Series 3. Pp 36-41, 2000.
HESSD

4, 2229-2271, 2007

Water productivity of conservation tillage systems

M. Temesgen et al.

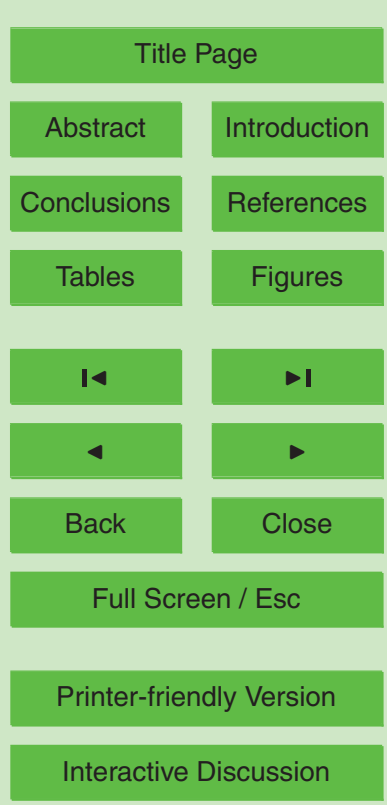

EGU 
Chen, J., HongWen, W., and Li, H. W.: Technology and Machinery System of Mechanized Conservation Tillage for Dry Land maize, J. China Agric. University, 3(4), 33-38, 1998.

Clark, M. D. and Gilmour, J. T.: The effect of temperature on decomposition at optimum and saturated soil water contents, Soil Sci. Soc. Am. J., 47, 927-929, 1983.

5 Engida, M.: A Desertification Convention Based on Moisture zones of Ethiopia, Ethiopian Journal of Natural Resources, 2000(1), 1-9, 2000.

Freitas, V. H.: Soil Management and Conservation for Small Farms. Strategies and Methods of Introduction, Technologies and Equipment. FAO Soils Bulletin 77. 31p, 2000.

Guzha, A. C.: Effects of tillage on soil microrelief, surface depression storage and soil water storage, Soil and Till. Res. 76, 105-114, 2004.

Heenan, D. P., Chan, K. Y., and Knight, P. G.: Long-term impact of rotation, tillage and stubble management on the loss of soil organic carbon and nitrogen from a Chromic Luvisol, Soil Tillage Res., 76, 59-68, 2004.

Hoogmoed, W. B.: Tillage for soil and water conservation in the semi-arid tropics, Doctoral

15 Thesis. Wageningen University, The Netherlands, 184p, 1999.

Hoogmoed, W. B., Stevens, P., Samazaka, D., and Buijsse, M.: Animal Draft Ripping: The Introduction of a Conservation Farming Technology in Zambia. In: 2004 CIGR Int. Conference, (W Zhicai and G Huangwen, Eds.) China Agricultural Science and Technology Press Beijing, China pp 393-399, 2004.

20 ISSS-ISRIC-FAO: World Reference Base for Soil Resources, World Soil Resources Report, 84, Rome, 1998.

Kijne, J. W., Barker, R., and Molden, D.: Water Productivity in Agriculture: Limits and Opportunities for Improvement. CABI Publishing, Wallingford, 2003.

Licht, M. A. and Al-Kaisi, M.: Strip-tillage effect on seedbed soil temperature and other soil physical properties, Soil Till. Res., 80, 233-249, 2005.

Ndiaye, B., Esteves, M., Vandervaere, J. P., Lapetite, J. M., and Vauclin, M.: Effect of rainfall and tillage direction on the evolution of surface crusts, soil hydraulic properties and runoff generationfor a sandy loam soil, J. Hydrol., 307, 294-311, 2005.

Ozpinar, S. and Cay, A.: Effect of different tillage systems on the quality and crop productivity of a clay-loam soil in semi-arid north-western Turkey, Soil Till. Res., 88, 95-106, 2006.

Pathak, B. S.: Survey of agricultural implements and crop production techniques. FAO Field Document 2, Eth/82/004. EARO, P. O. Box 2003, Addis Ababa, Ethiopia. 36p, 1987.

Rockström, J.: Water for food and nature in drought-prone tropics: vapour shift in rain-fed
HESSD

4, 2229-2271, 2007

\section{Water productivity of conservation tillage systems}

M. Temesgen et al.

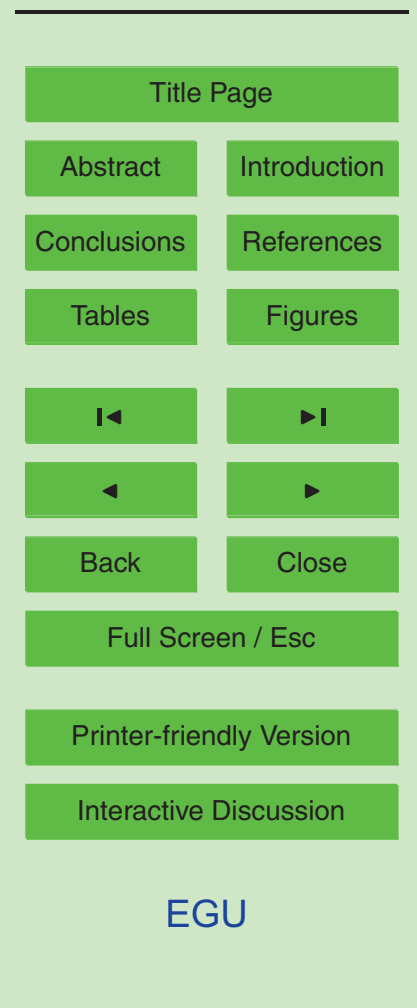


agriculture, Phil. Trans. R. Soc. Lond. B, 358, 1997-2009, 2003.

Rockström, J. and Jansson, L.: Conservation Tillage Systems for Dryland Farming: On-farm Research and Extension Experiences, E. Afr. Agric. For. J., 65(2), 101-114, 1999.

Rockström, J.: On-farm agrohydrological analysis of the Sahelian yield crisis: rainfall partitioning, soil nutrients and water use efficiency of pearl millet. PhD thesis. Natural Resources management department of systems Ecology. Stockholm University. Stockholm, Sweden, 1997.

Rockström, J., Valentin, C.: Hillslope dynamics of on-farm water flows: The case of rain-fed cultivation of pearl millet on sandy soil in the Sahel, Agric. Water Manage., 33, 183-210, 1997.

Rowland, J. R. J (Ed): Dryland Farming in Africa. Published by Macmillan Education Ltd. in cooperation with the CTA, Postbus 380, 6700 AJ Wageningen, The Netherlands. 83p, 1993.

SAS Institute Inc.: SAS/STAT User's Guide, Version 8. Cary, NC, USA, 1999.

Savenije, H. G.: Determination of evaporation from a catchment water balance at a momthly time scale. Hydrology and Earth System Sciences, 1, 93-100, 1997.

Savenije, H. G.: The importance of interception and why we should delete the term evapotranspiration from our vocabulary, Hydrol. Process., 18, 1507-1511, 2004.

Steiner, K. G. (Ed): Conserving Natural resources and Enhancing Food Security by Adopting No-Tillage. An Assessment of the Potential for Soil-conserving Production Systems in Various Agro-ecological Zones of Africa. Published by GTZ. Postfach 5180. D-65726 Eschborn. 47p, 1998.

Stewart, D. W. and Dwyer, L. M.: Mathematical Characterization of Leaf Shape and Area of Maize Hybrids. Crop Sci. 39:422-427, 1999.

Su, Y., Zhao, H., Zhang, T., and Zhao, X.: Soil properties following cultivation and non-grazing of a semi-arid sandy grassland in northern China. Soil and Till. Res. 75, 27-36, 2004.

Taddele, Z.: tef in the Farming Systems of the Ada Area. Research Report No. 24. Institute of Agricultural Research, Addis Ababa, Ethiopia, 1994.

Teklu, E. and Gezahegn, A.: Indigenous Knowledge and Practices for Soil and Water Management in East Wollega, Ethiopia, in: Technological and Institutional Innovations for SusTropentag 2003. Göttingen, October 8-10, 2003 http://www.tropentag.de, 2003.

Temesgen, M.: Conservation Tillage Systems and Water Productivity Implications for Smallholder Farmers in Semi-arid Ethiopia. PhD Thesis. Taylor \& Francis/Balkema, Leiden, The

HESSD

4, 2229-2271, 2007

\section{Water productivity of conservation tillage systems}

M. Temesgen et al.

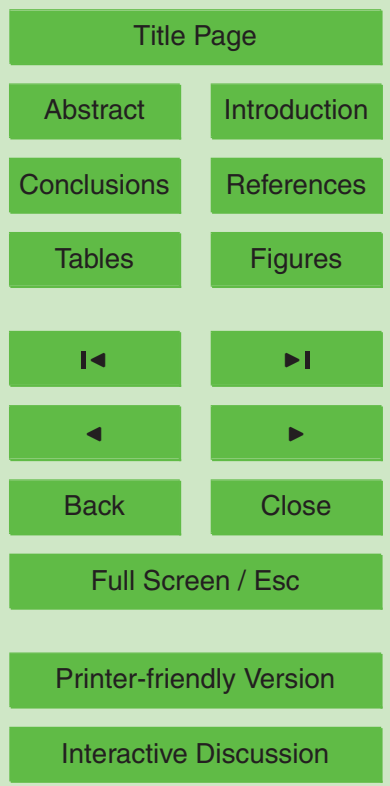

EGU 
Netherlands, 2007.

Van Reeuwijk, L. P.: Procedures for Soil Analysis. International Soil Reference and Information Center, Netherlands, 1993

West, T. O. and Post, W. M.: Soil organic carbon sequestration rates by tillage and crop rotation: a global data analysis, Soil Sci. Soc. Am. J., 66, 1930-1946, 2002.

Zekaria, S.: Innovative and Successful Technical Experience in the Production of Agricultural Statistics and Food Security of Ethiopia, p.16, Central Statistical Authority, Addis Ababa, 2002.

\section{HESSD}

4, 2229-2271, 2007

Water productivity of conservation tillage systems

M. Temesgen et al.

Title Page

Abstract Introduction

Conclusions References

Tables Figures

14

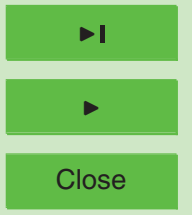

Back

Full Screen / Esc

Printer-friendly Version

Interactive Discussion 


\section{HESSD}

4, 2229-2271, 2007

Water productivity of conservation tillage systems

Table 1. Parameters used in the conceptual model.

M. Temesgen et al.

\begin{tabular}{llll}
\hline Property & Value & Unit & Source \\
\hline Crop coefficient, $K_{C}$ & 0.65 & & \\
Moisture content at field capacity, $S_{F C}$ & 17 & $\%$ & Measured \\
Moisture content at wilting point, $S_{W}$ & 9 & $\%$ & Measured \\
$p$ & 0.4 & & Assumed \\
$r$ & 0.3 & & Assumed \\
Interception threshold, $I_{D}$ & 4 & $\mathrm{~mm}-\mathrm{d}^{-1}$ & Assumed \\
Leaf overlap factor, $C_{C}$ & 0.9 & & Field observation \\
Soil evaporation coefficient, $K_{S}$ & 0.5 & & Assumed \\
Drainage coefficient, $R_{C}$ & 0.03 & & Assumed \\
\hline
\end{tabular}

Title Page

Abstract

Introduction

Conclusions

References

Tables

Figures

14

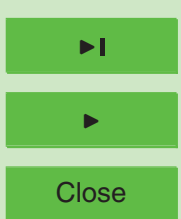

Back

Close

Full Screen / Esc

Printer-friendly Version

Interactive Discussion 


\section{HESSD}

4, 2229-2271, 2007

\section{Water productivity of conservation tillage systems}

M. Temesgen et al.

Table 2. Physical and chemical properties of soils at the initiation of the experiment at Melkawoba.

\begin{tabular}{llll}
\hline $\begin{array}{l}\text { Soil texture } \\
\text { (Particle size distribution in \%) }\end{array}$ & Sand & Silt & Clay \\
\cline { 2 - 4 } & 64 & 25 & 11 \\
Bulk density $\left(\mathrm{gm} \mathrm{cm}^{-3)}\right.$ & 1.36 & & \\
Organic carbon (\%) & 0.65 & & \\
Total Nitrogen (\%) & 0.08 & & \\
\hline
\end{tabular}

Title Page

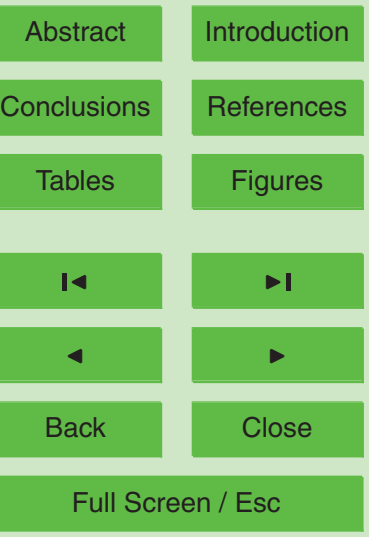

Printer-friendly Version

Interactive Discussion 


\section{HESSD}

4, 2229-2271, 2007

Water productivity of conservation tillage systems

M. Temesgen et al.

Table 3a. Effect of tillage systems on water balance $\left(\mathrm{mm} \text {-season }{ }^{-1}\right)^{1}$ at Melkawoba, 2005. (Results from conceptual model).

\begin{tabular}{lllllllllll}
\hline Treatment & $P$ & $Q s$ & $I$ & $T$ & $E s$ & $R$ & $\Delta S$ & $T / P$ & $Q s / P$ & $(I+E s) / P$ \\
\hline CONV & 355 & 40 & 100 & 158 & 39 & 56 & -37 & 0.44 & 0.11 & 0.39 \\
STS & 355 & 17 & 100 & 196 & 25 & 54 & -36 & 0.55 & 0.05 & 0.35 \\
ST & 355 & 25 & 100 & 178 & 31 & 57 & -36 & 0.50 & 0.07 & 0.37 \\
\hline
\end{tabular}

Title Page

Abstract

Introduction

Conclusions

References

Tables

Figures

${ }^{1}$ Season refers to period between seedling emergence and harvesting.

14

4

Back

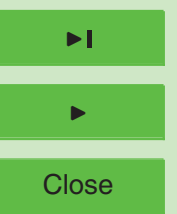

Full Screen / Esc

Printer-friendly Version

Interactive Discussion 


\section{HESSD}

4, 2229-2271, 2007

Water productivity of conservation tillage systems

M. Temesgen et al.

Table 3b. Effect of tillage systems on water balance $\left(\mathrm{mm} \text {-season }{ }^{-1}\right)^{2}$ at Melkawoba, 2004. (Results from conceptual model).

\begin{tabular}{lllllllllll}
\hline Treatment & $P$ & $Q s$ & $I$ & $T$ & $E s$ & $R$ & $\Delta S$ & $T / P$ & $Q s / P$ & $(I+E s) / P$ \\
\hline CONV & 305 & 61 & 70 & 94 & 105 & 86 & -41 & 0.31 & 0.20 & 0.77 \\
STS & 305 & 26 & 70 & 98 & 122 & 95 & -35 & 0.32 & 0.08 & 0.71 \\
ST & 305 & 35 & 70 & 91 & 127 & 91 & -39 & 0.30 & 0.11 & 0.76 \\
\hline
\end{tabular}

Title Page

Abstract

Introduction

Conclusions

References

Tables

Figures

${ }^{2}$ Season refers to period between seedling emergence and harvesting.

14

4

Back

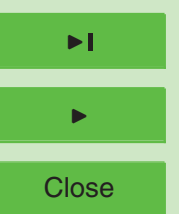

Full Screen / Esc

Printer-friendly Version

Interactive Discussion 


\section{HESSD}

4, 2229-2271, 2007

Water productivity of conservation tillage systems

M. Temesgen et al.

Table 3c. Effect of tillage systems on water balance $\left(\mathrm{mm} \text {-season }{ }^{-1}\right)^{3}$ at Melkawoba, 2003. (Results from conceptual model).

\begin{tabular}{lllllllllll}
\hline Treatment & $P$ & $Q s$ & $I$ & $T$ & $E s$ & $R$ & $\Delta S$ & $T / P$ & $Q s / P$ & $(I+E s) / P$ \\
\hline CONV & 420 & 100 & 145 & 114 & 80 & 175 & -49 & 0.27 & 0.24 & 0.77 \\
STS & 420 & 42 & 145 & 149 & 77 & 191 & -40 & 0.36 & 0.10 & 0.63 \\
ST & 420 & 57 & 145 & 143 & 86 & 177 & -43 & 0.34 & 0.14 & 0.69 \\
\hline
\end{tabular}

Title Page

Abstract

Introduction

Conclusions

References

Tables

Figures

${ }^{3}$ Season refers to period between seedling emergence and harvesting.

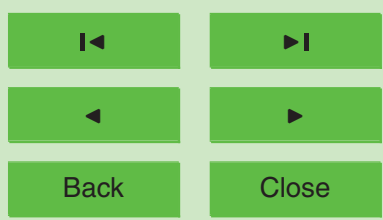

Full Screen / Esc

Printer-friendly Version

Interactive Discussion 


\section{HESSD}

4, 2229-2271, 2007

Water productivity of conservation tillage systems

Table 4. Effect of tillage system on grain yield of maize $\left(\mathrm{kg}^{-\mathrm{ha}} \mathrm{C}^{-1}\right)$.

\begin{tabular}{lllllllll}
\hline Treatments & \multicolumn{3}{c}{ Melkawoba } & \multicolumn{5}{c}{ Wulinchity } \\
\cline { 3 - 9 } & 2003 & 2004 & $2005^{4}$ & $2005^{5}$ & Mean & 2003 & 2004 & Mean \\
\hline CONV & 1390 & 1070 & 2100 & 1720 & 1570 & 1170 & 1610 & 1390 \\
STS & 1430 & 920 & 1650 & 2130 & 1530 & 1200 & 1480 & 1340 \\
ST & 1520 & 1010 & 2000 & 1840 & 1590 & 1170 & 1600 & 1380 \\
& NS & NS & NS & NS & & NS & NS & \\
Rainfall $\left(m m-\mathrm{yr}^{-1}\right)$ & 611 & 548 & 588 & 588 & & 786 & 580 & \\
\hline
\end{tabular}

${ }^{4}$ Medium maturing maize variety, Limat.

${ }^{5}$ Early maturing maize variety, Katumani.

M. Temesgen et al.

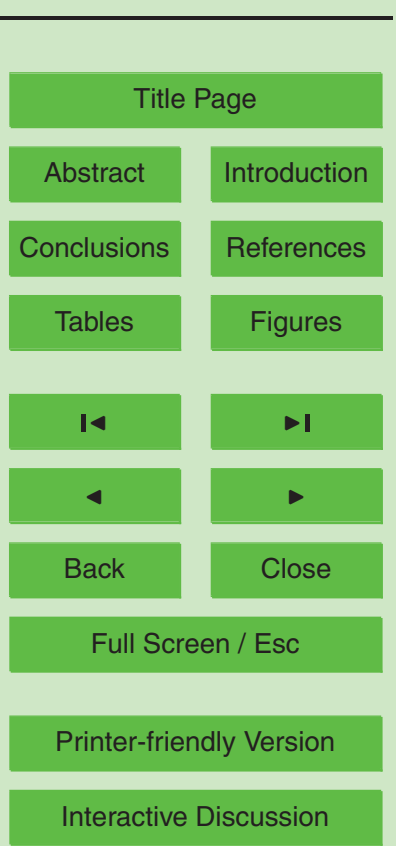




\section{HESSD}

4, 2229-2271, 2007

Water productivity of conservation tillage systems

Table 5. Effect of closing furrows in STS/ST on grain and biomass of medium maturing maize (Melkawoba, 2005).

\begin{tabular}{|c|c|c|}
\hline Treatment & $\begin{array}{l}\text { Grain yield } \\
\left(\mathrm{kg} \mathrm{ha}^{-1}\right)\end{array}$ & 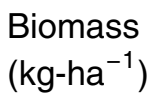 \\
\hline Open STS & 993 (c) & 3576 (c) \\
\hline Open ST & $1250(\mathrm{bc})$ & 4347 (bc) \\
\hline Closed STS & $1332(a b)$ & $4875(a b)$ \\
\hline Closed ST & $1587(\mathrm{a})$ & 5750 (a) \\
\hline
\end{tabular}

Title Page

Abstract

Introduction

Conclusions

References

Tables

Figures

4

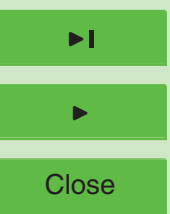

Back

Close

Full Screen / Esc

Printer-friendly Version

Interactive Discussion 


\section{HESSD}

4, 2229-2271, 2007

Water productivity of conservation tillage systems

M. Temesgen et al.

Table 6. Effect of fertilization on grain yield of maize.

\begin{tabular}{|c|c|c|c|c|}
\hline Treatment & Melkawoba & & Wulinchit & \\
\hline & 2003 & 2004 & 2003 & 2004 \\
\hline Fertilized & 1479 & 1146 & 1317 & 1668 \\
\hline \multirow[t]{2}{*}{ Un fertilized } & 1408 & 860 & 1040 & 1461 \\
\hline & NS & $P>90 \%$ & $P>95 \%$ & $P>95 \%$ \\
\hline Fertilizer $\mathrm{x}$ Tillage & NS & & NS & NS \\
\hline
\end{tabular}

Title Page

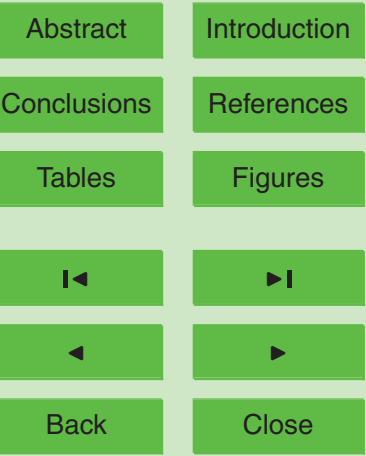

Full Screen / Esc

Printer-friendly Version

Interactive Discussion 


\section{HESSD}

4, 2229-2271, 2007

Water productivity of conservation tillage systems

M. Temesgen et al.

Table 7. Water productivity $\left(\mathrm{kg}_{\text {grain }} \mathrm{m}^{-3}\right)$ as affected by tillage systems in maize.

\begin{tabular}{llllllllll}
\hline & \multicolumn{3}{c}{ Melkawoba 2005} & \multicolumn{3}{c}{ Melkawoba 2004} & \multicolumn{3}{c}{ Melkawoba 2003 } \\
\hline Treatment & $W_{P T}$ & $W_{\mathrm{PET}}$ & $W_{P P}$ & $W_{P T}$ & $W_{\mathrm{PET}}$ & $W_{P P}$ & $W_{P T}$ & $W_{\mathrm{PET}}$ & $W_{P P}$ \\
\hline CONV & 11.4 & 4.8 & 4.8 & 11.4 & 4.0 & 3.5 & 12.2 & 4.1 & 3.3 \\
STS & 11.7 & 5.8 & 6.0 & 9.4 & 3.2 & 3.0 & 9.6 & 3.9 & 3.4 \\
ST & 11.1 & 3.8 & 5.2 & 11.1 & 3.5 & 3.3 & 10.6 & 4.1 & 3.6 \\
\hline
\end{tabular}

Title Page

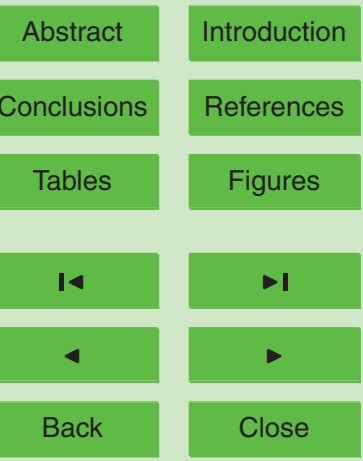

Full Screen / Esc

Printer-friendly Version

Interactive Discussion 


\section{HESSD}

4, 2229-2271, 2007

Water productivity of conservation tillage systems

M. Temesgen et al.

Table 8. Effect of tillage systems on soil physical and chemical properties.

\begin{tabular}{lllll}
\hline Treatment & Total Nitrogen (\%) & Organic Carbon (\%) & Bulk density $\left(\mathrm{gm} \mathrm{cm}^{-3}\right)$ & $\mathrm{pH}$ in $\mathrm{H}_{2} \mathrm{O}$ \\
\hline CONV & 0.074 & 0.62 & 1.35 & 8.18 \\
STS & 0.082 & 0.62 & 1.38 & 8.25 \\
ST & 0.079 & 0.64 & 1.39 & 8.23 \\
& NS & NS & NS & NS \\
\hline
\end{tabular}

Title Page

Abstract

Introduction

Conclusions

References

Tables

Figures

14

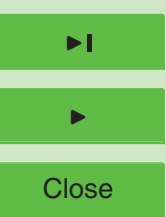

Back

Close

Full Screen / Esc

Printer-friendly Version

Interactive Discussion 


\section{HESSD}

4, 2229-2271, 2007

\section{Water productivity of conservation tillage systems}

M. Temesgen et al.

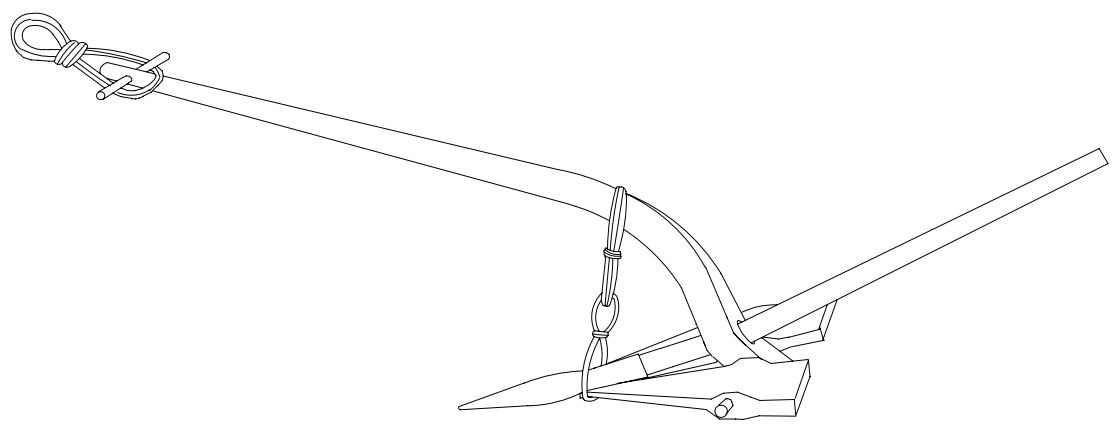

Title Page

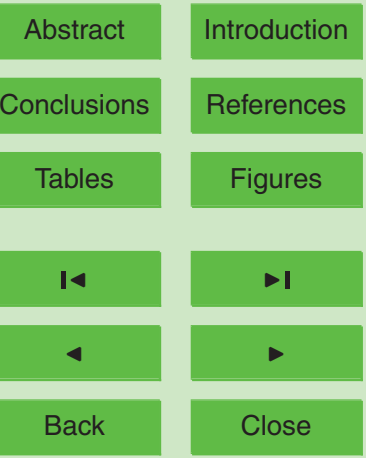

Full Screen / Esc

Printer-friendly Version

Interactive Discussion 


\section{HESSD}

4, 2229-2271, 2007

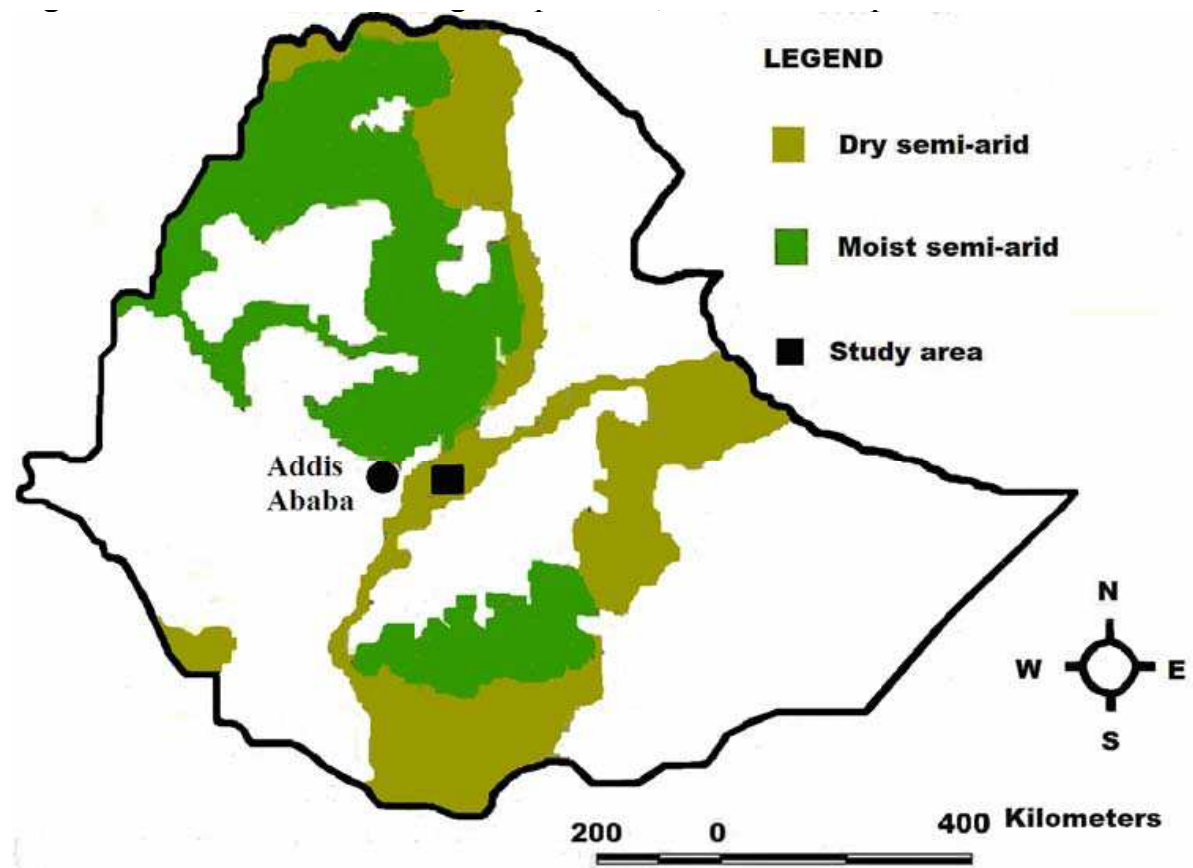

Water productivity of conservation tillage systems

M. Temesgen et al.

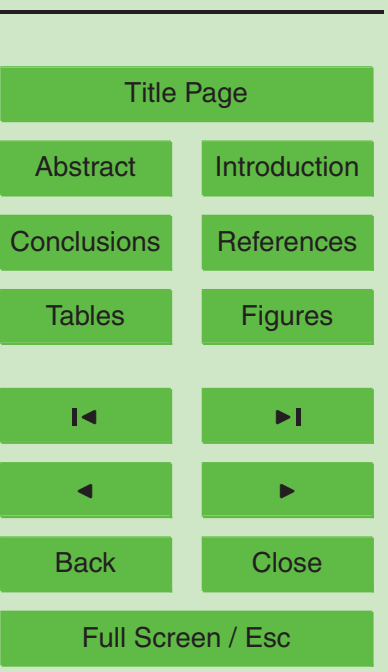

Fig. 2. Semi arid areas in Ethiopia. (Source: IGAD and FAO, 1995). Areas with length of growing period in the range of 60 to 119 days are classified as dry semi-arid while areas with a length of growing period of 120-179 days are classified as moist semi-arid.

Printer-friendly Version

Interactive Discussion 


\section{HESSD}

4, 2229-2271, 2007

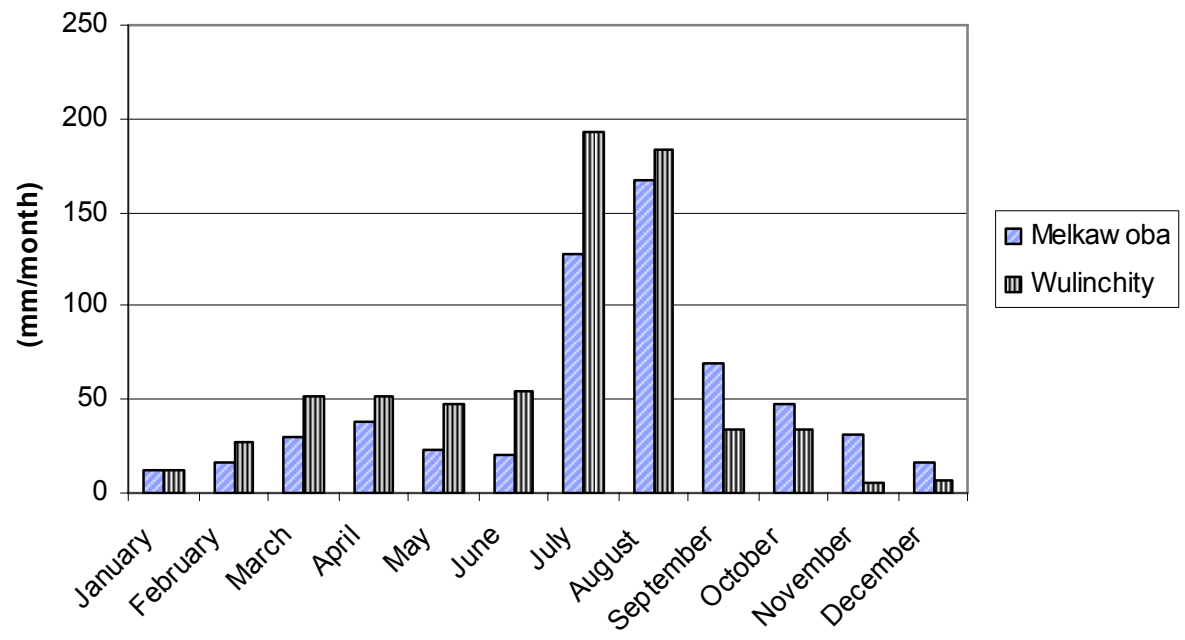

\section{Water productivity of conservation tillage systems}

M. Temesgen et al.

Title Page

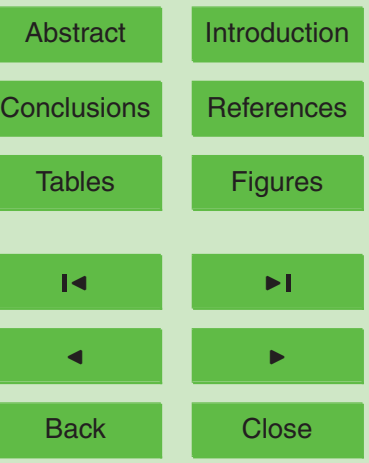

Full Screen / Esc

Printer-friendly Version

Interactive Discussion 


\section{HESSD}

4, 2229-2271, 2007

\section{Water productivity of conservation tillage systems}

M. Temesgen et al.

Title Page

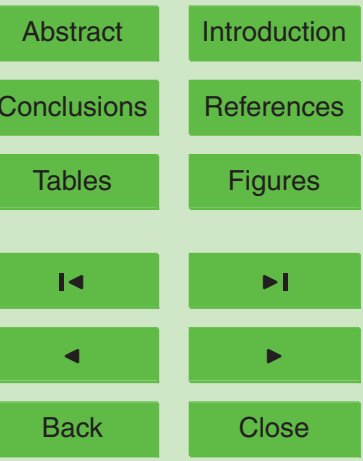

Full Screen / Esc

Printer-friendly Version

Interactive Discussion 


\section{HESSD}

4, 2229-2271, 2007

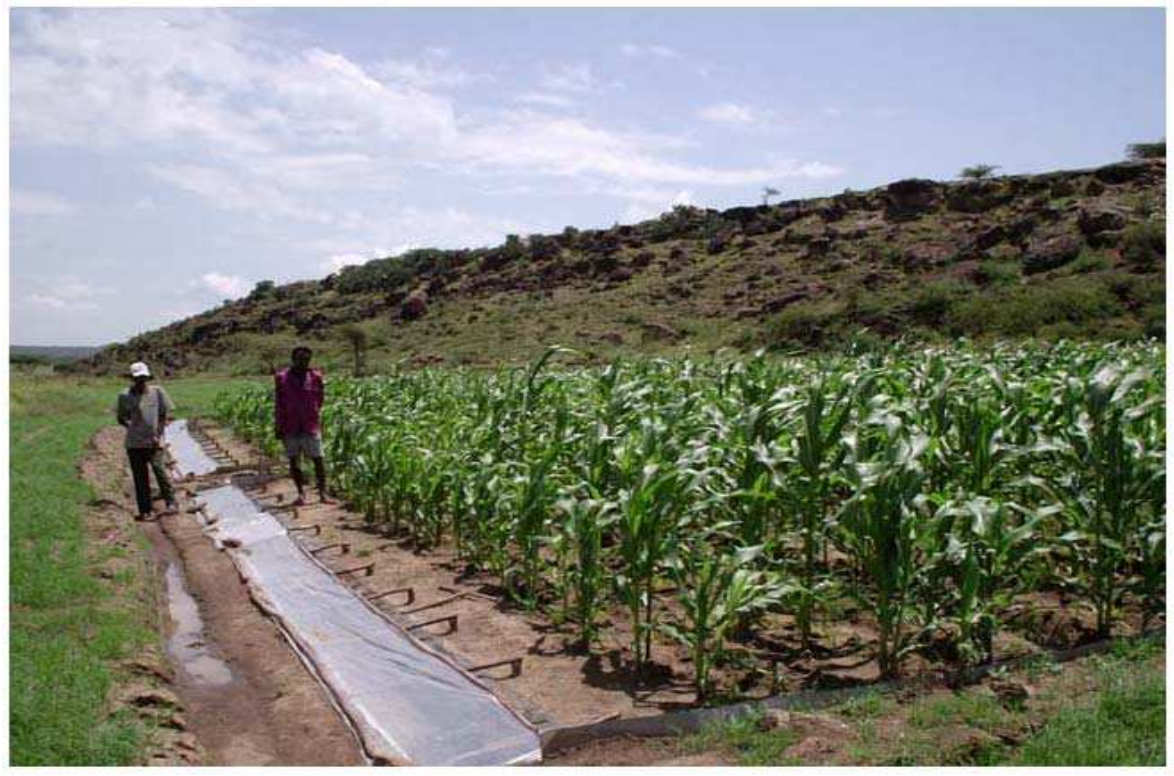

\section{Water productivity of conservation tillage systems}

M. Temesgen et al.

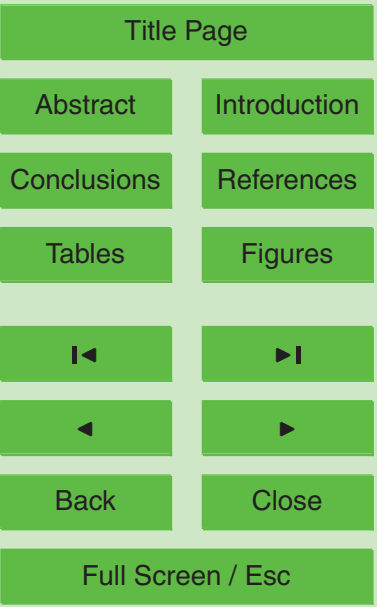

Fig. 5. Surface runoff collecting trough covered with hanging plastic sheets to prevent direct precipitation.

Printer-friendly Version

Interactive Discussion

EGU 


\section{HESSD}

4, 2229-2271, 2007

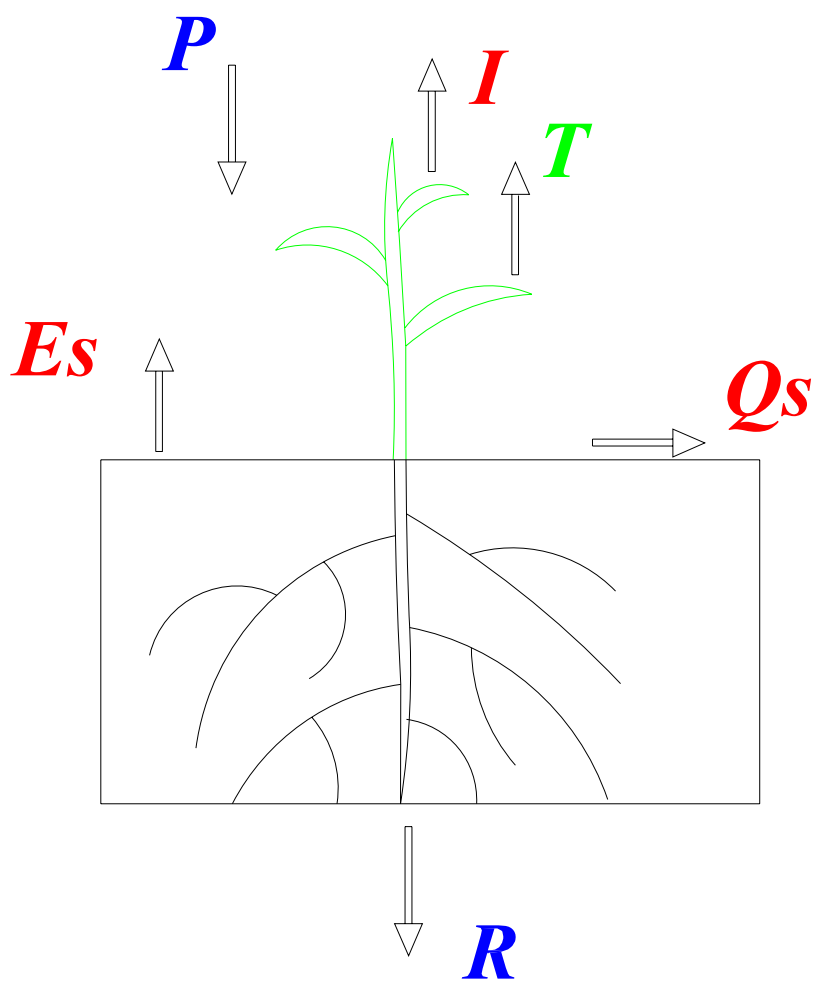

Root zone (1m)

\section{Water productivity of conservation tillage systems}

M. Temesgen et al.

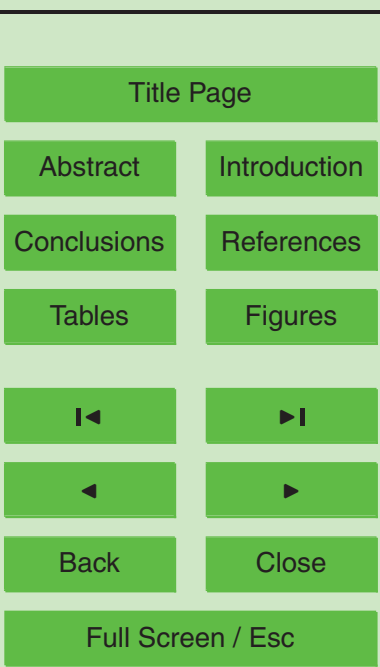

Fig. 6. Conceptual model for rainfall partitioning in maize.

Printer-friendly Version

Interactive Discussion 


\section{HESSD}

4, 2229-2271, 2007

\section{Water productivity of conservation tillage systems}

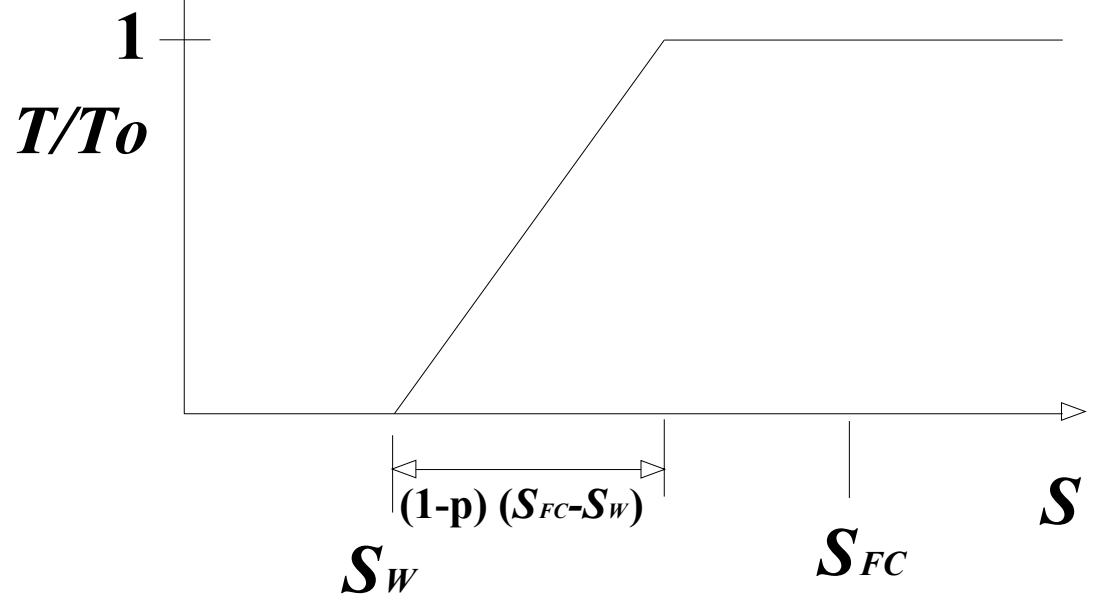

Fig. 7. Ratio of actual and maximum plant transpiration (T/To) as affected by soil moisture. $T$ : Actual plant transpiration, To: Maximum plant transpiration when there is no limitations due to moisture stress, $S_{W}$ : Wilting point, $S_{F C}$ : Soil moisture at field capacity and (1-p)( $\left.S_{F C}-S_{W}\right)$ : proportion of plant available water below which $T$ starts to be less than To.
M. Temesgen et al.

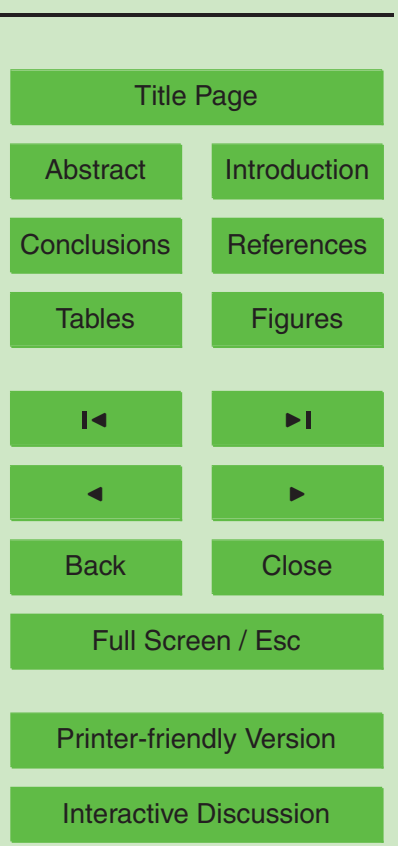




\section{HESSD}

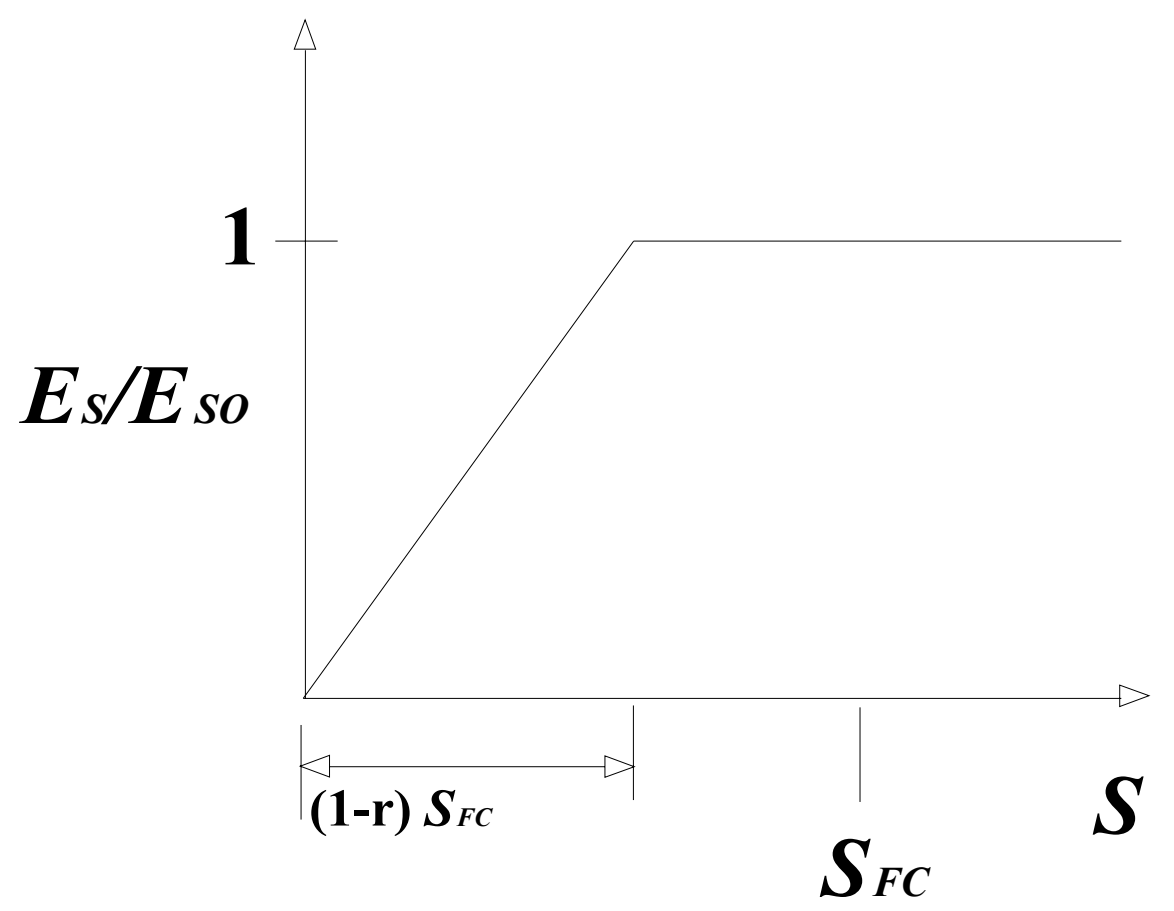

4, 2229-2271, 2007

Water productivity of conservation tillage systems

M. Temesgen et al.

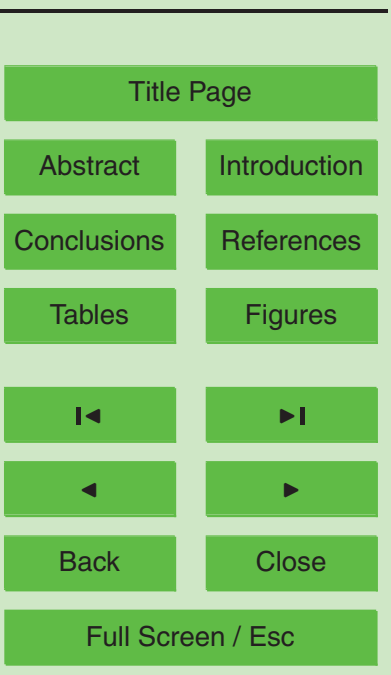

Fig. 8. Ratio of actual and maximum soil evaporation $\left(E_{S} / E_{S O}\right)$ as affected by soil moisture. $E_{S}$ : Actual soil evaporation, $E_{S O}$ : Maximum soil evaporation when there is no limitations due to moisture stress, $S_{F C}$ : Soil moisture at field capacity and $(1-r) S_{F C}$ : proportion of soil moisture Printer-friendly Version below which $E_{S}$ starts to be less than $E_{S O}$. 


\section{HESSD}

4, 2229-2271, 2007

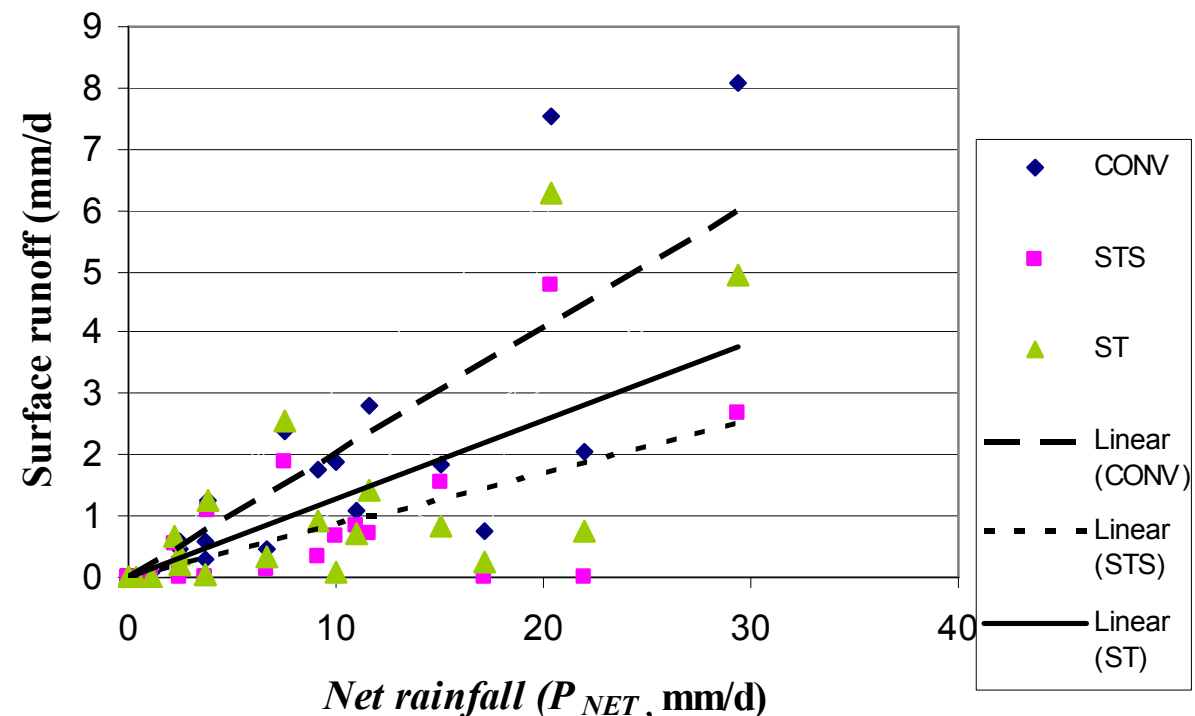

Fig. 9. Surface runoff as affected by tillage systems (Melkawoba, 2005). $P_{\mathrm{NET}}$ is obtained after subtracting runoff threshold of each treatment from the total rainfall.

\section{Water productivity of conservation tillage systems}

M. Temesgen et al.

Title Page

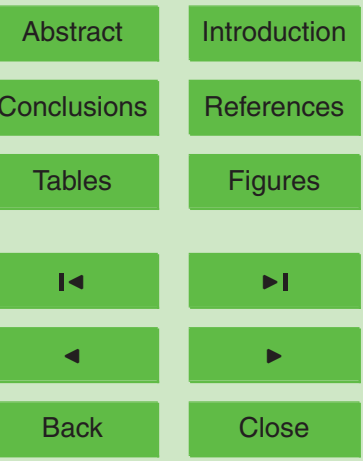

Full Screen / Esc

Printer-friendly Version

Interactive Discussion 


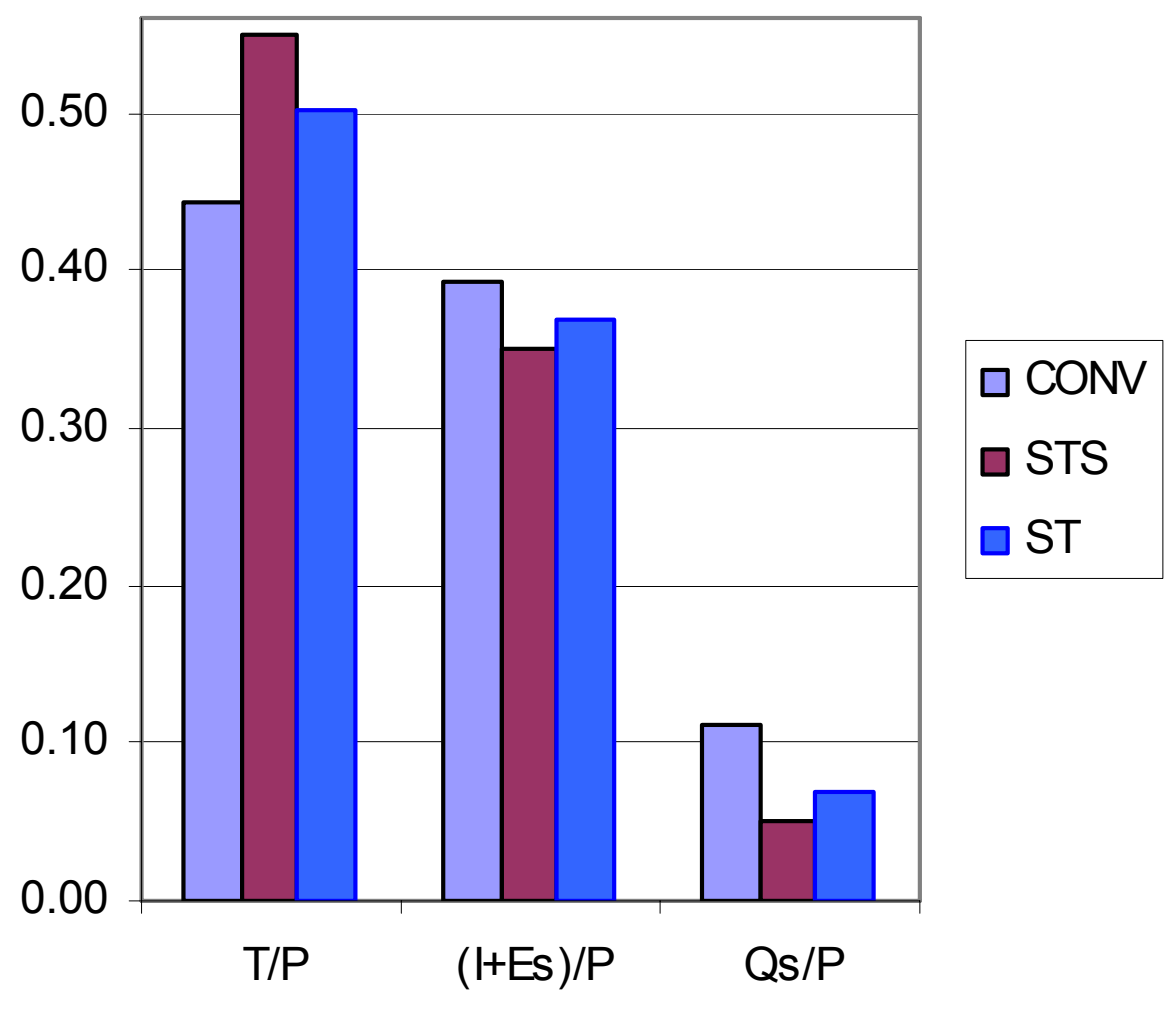

Flux ratio

Fig. 10. Ratio of productive (transpiration), non productive (interception, soil evaporation) and runoff to total precipitation as affected by tillage systems.

\section{HESSD}

4, 2229-2271, 2007

Water productivity of conservation tillage systems

M. Temesgen et al.

Title Page

Abstract

Introduction

Conclusions

References

Tables

Figures

I

I

4

Back

Close 


\section{HESSD}

4, 2229-2271, 2007

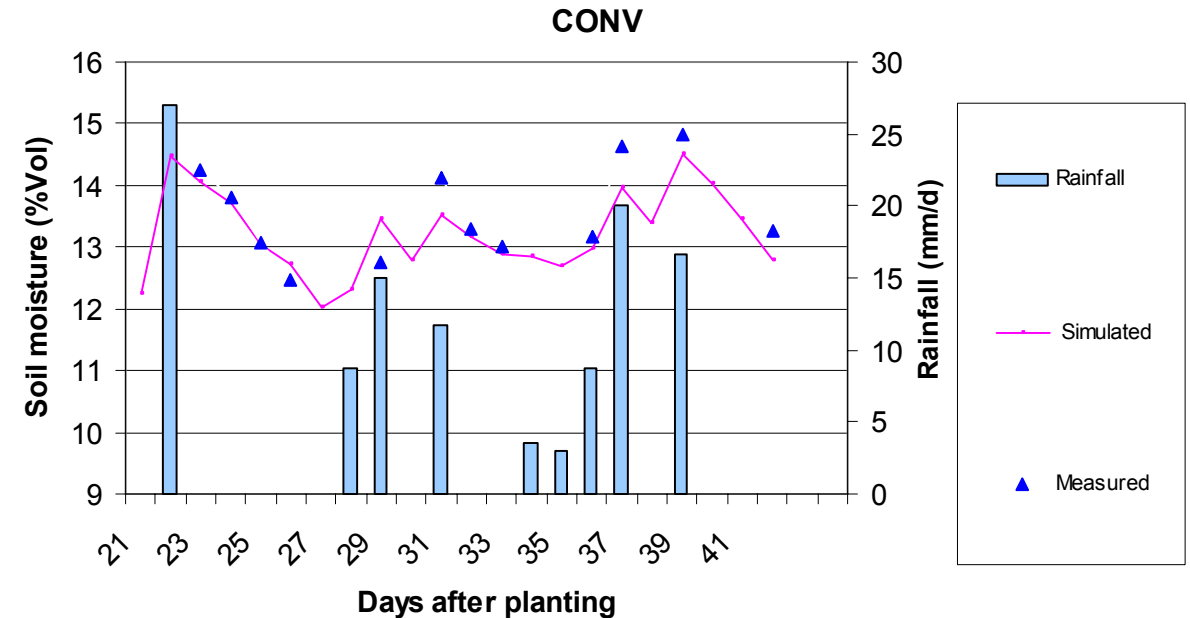

Water productivity of conservation tillage systems

M. Temesgen et al.

Title Page

Abstract

Introduction

Conclusions

References

Tables

Figures

14

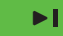

4

Back

Close

\section{Full Screen / Esc}

Printer-friendly Version

Interactive Discussion

EGU 


\section{HESSD}

4, 2229-2271, 2007

\section{Water productivity of conservation tillage systems}

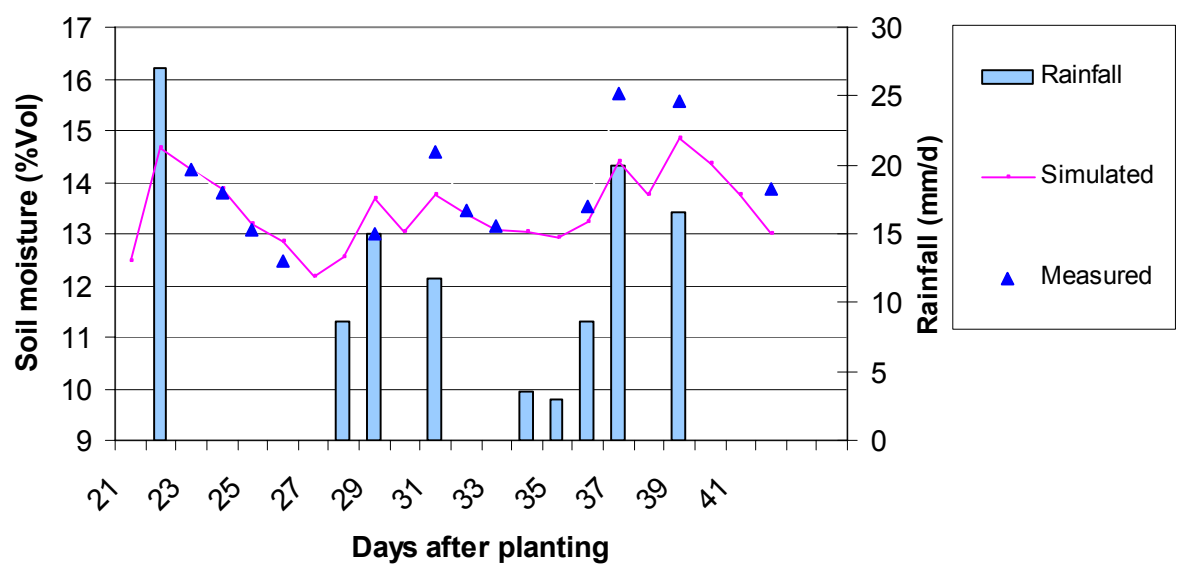

M. Temesgen et al.

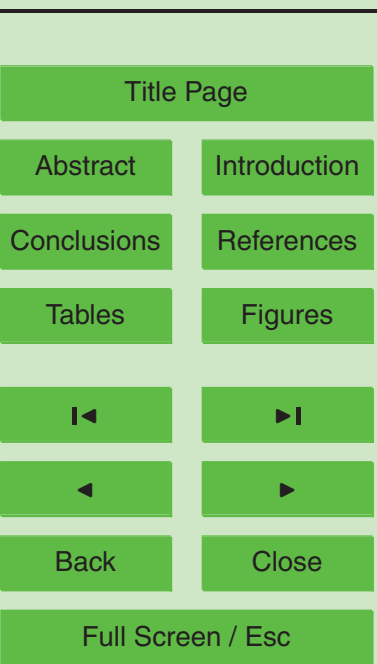

Printer-friendly Version

Interactive Discussion 


\section{HESSD}

4, 2229-2271, 2007

ST

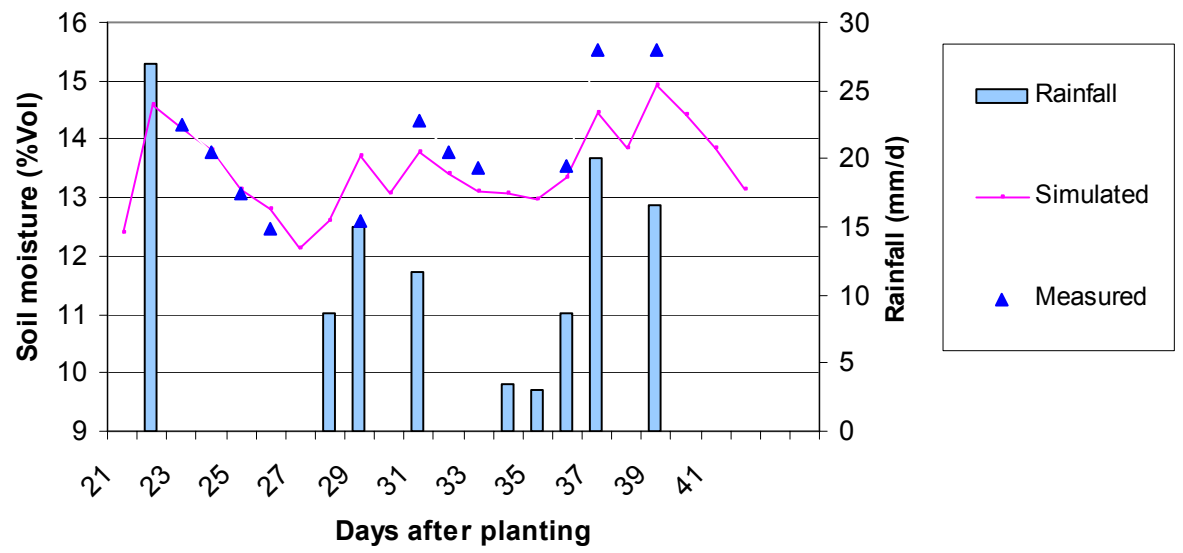

Fig. 11c. Validation of simulated soil moisture over the root zone $(0-1 \mathrm{~m})$ in ST using measured values. (Melkawoba, 2005).

\section{Water productivity of conservation tillage systems}

M. Temesgen et al.

Title Page

Abstract

Introduction

Conclusions

References

Tables

Figures

I

4

Back

\section{Full Screen / Esc}

Printer-friendly Version

Interactive Discussion 


\section{HESSD}

4, 2229-2271, 2007

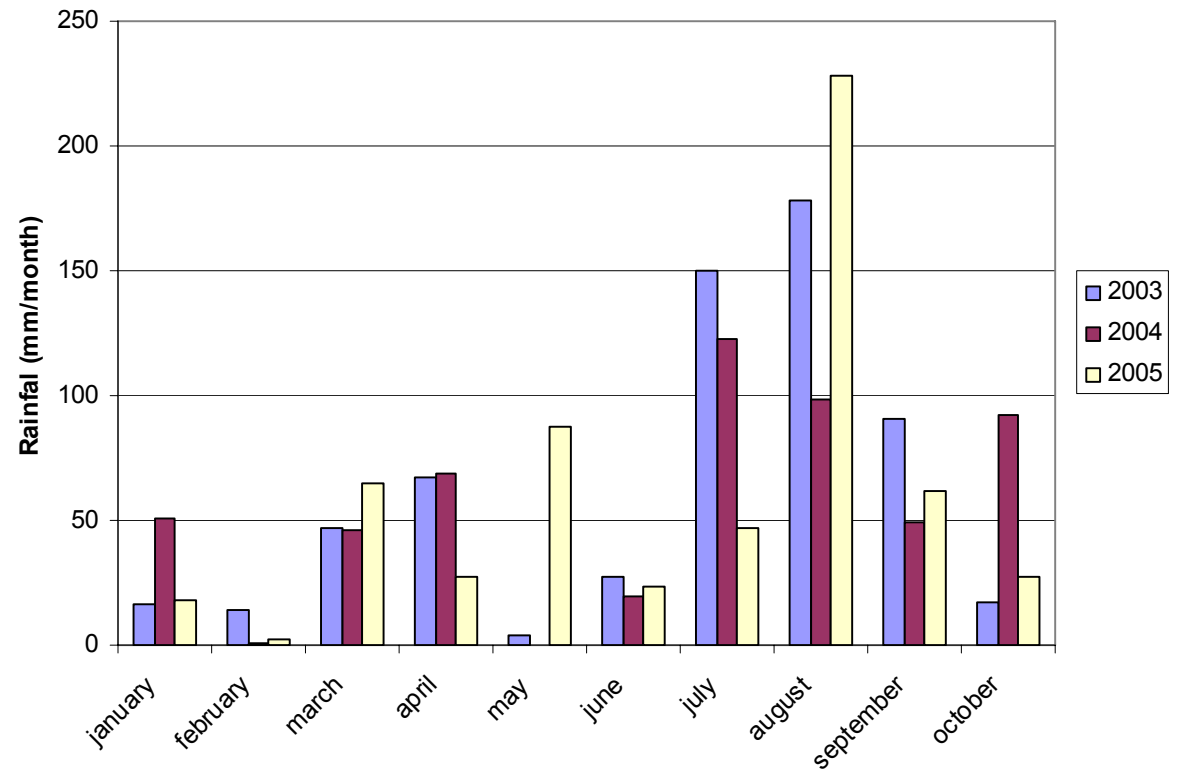

\section{Water productivity of conservation tillage systems}

M. Temesgen et al.

Title Page

Abstract

Introduction

Conclusions

References

Tables

Figures

14

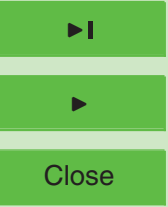

Back

Close

Full Screen / Esc

Printer-friendly Version

Interactive Discussion

EGU 


\section{HESSD}

4, 2229-2271, 2007

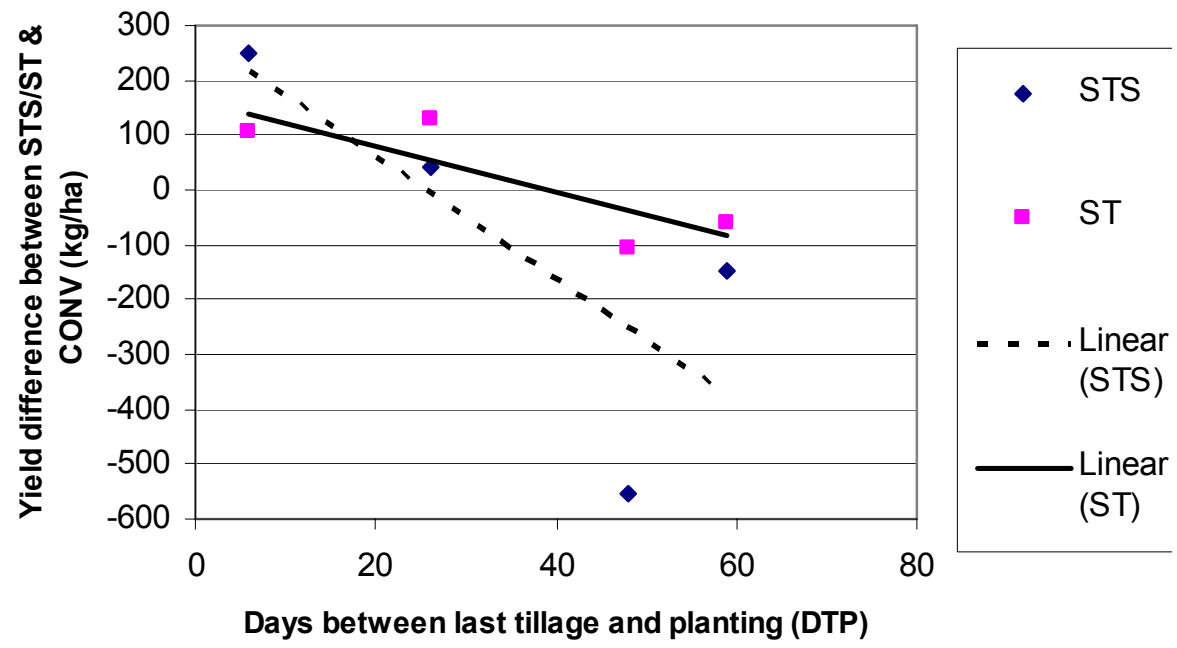

Water productivity of conservation tillage systems

M. Temesgen et al.

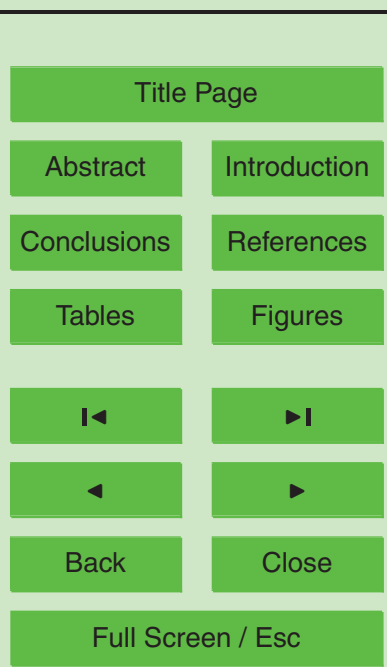

Fig. 13. Performance of conservation tillage systems in relation to days between last tillage and planting (DTP).

Full Screen / Esc

Printer-friendly Version

Interactive Discussion 